\title{
Working
}

Paper 


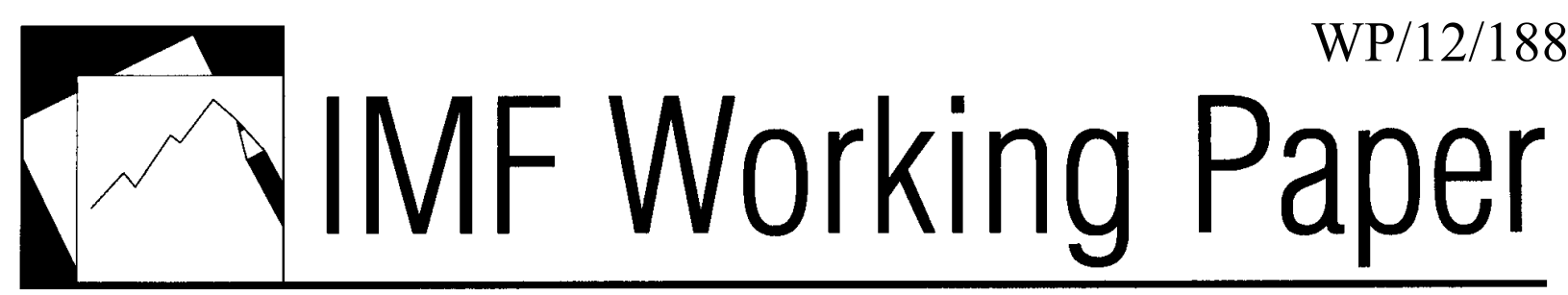

Riding Global Financial Waves: The Economic Impact of Global Financial Shocks on Emerging Market Economies

Gustavo Adler and Camilo E. Tovar 


\title{
IMF Working Paper
}

Western Hemisphere Department

\section{Riding Global Financial Waves: The Economic Impact of Global Financial Shocks on Emerging Market Economies*}

\author{
Prepared by Gustavo Adler and Camilo E. Tovar
}

Authorized for distribution by Charles Kramer

July 2012

\section{This Working Paper should not be reported as representing the views of the IMF.}

The views expressed in this Working Paper are those of the author(s) and do not necessarily represent those of the IMF or IMF policy. Working Papers describe research in progress by the author(s) and are published to elicit comments and to further debate.

\begin{abstract}
Over the past two decades, most emerging market economies witnessed two key developments. A marked process of financial integration with the rest of the world, arguably turning these economies more vulnerable to global financial shocks; and an improvement of macroeconomic fundamentals, helping to increase their resiliency to these shocks. Against a backdrop of these opposing forces, are these economies more vulnerable to global financial shocks today than in the past? Have better fundamentals offset increasing financial integration? If so, what fundamentals matter most? We address these questions by examining the role of these two forces over the past two decades in amplifying or buffering the economic impact of these shocks. Our findings show that EMEs, with the exception of Emerging Europe, have become less vulnerable. Exchange rate flexibility and external sustainability are key determinants of the impact of these shocks, while the extent to which deeper financial integration is a source of vulnerability depends on the exchange rate regime.
\end{abstract}

JEL Classification Numbers: E44, F36, F44, F47

Keywords: global financial shocks, spillovers, emerging markets

Authors' E-Mail Addresses: gadler@imf.org; ctovar@imf.org

* We are grateful to Nicolas Eyzaguirre, Miguel Savastano, Charles Kramer, Luis Cubeddu, Sebastian Sosa, and seminar participants at the Central Banks of Colombia and Peru and the New York Federal Reserve for their useful comments and feedback. Finally, we thank Andresa Lagerborg for her excellent research assistance. 
Contents

Page

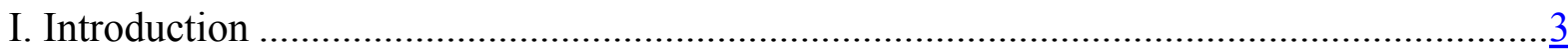

II. Recurrent Episodes of Global Financial Stress …………..............................................

III. Financial Integration and Economic Fundamentals: Acting in Opposing Directions?........

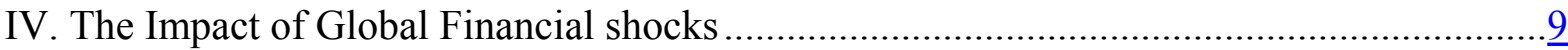

A. Sample, Data, and Econometric Approach ………...............................................

B. Cross-Sectional Results ...................................................................................

V. Assessing Vulnerabilities: Simulation Analysis ...........................................................

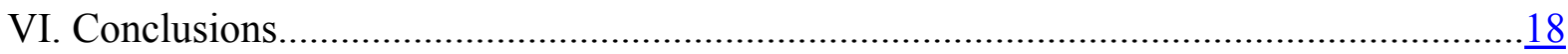

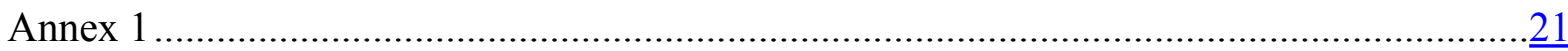

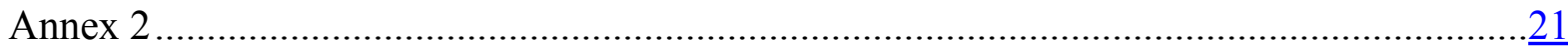

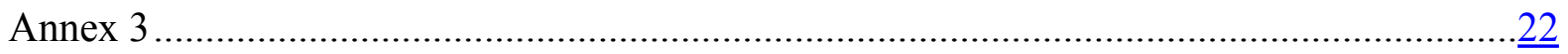

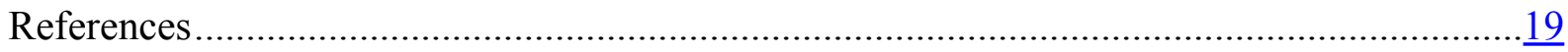

Figures

1. Global Financial Shocks, 1990-2011 ……………................................................... $\underline{5}$

2. Key Variables during Episodes of Global Financial Shocks, 1990-2011 ……................... $\underline{6}$

3. Financial Openness, 1990-2011 ………………................................................. $\frac{7}{8}$

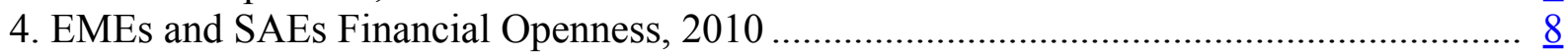

5. Macroeconomic Fundamentals, 1990-2010 ………................................................. 9

6. Key Macroeconomic Fundamentals in EMEs and SAEs, 2010 versus 2000 .......................10

7. Output Performance during Global Financial Shocks, 1990-2011 …..............................11

8. Output Performance during Global Financial Shocks, 1990-2011 …..............................12

9. Output Performance and Fundamentals during Global Financial Shocks, 1990-2011 ….....14

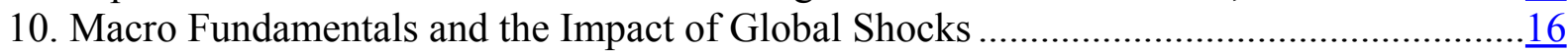

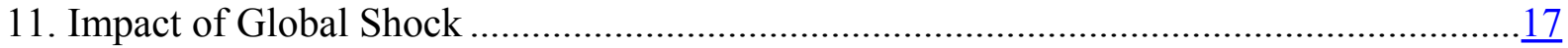

Tables

1. Global Financial Shocks, 1990-2011 …………......................................................

2. Main Results of Cross-Section Estimation .....................................................................

Annex 1. Key Global Variables during Global Financial Shocks, 1990-2011 ……….............21

Annex 2. Exchange Rate Pressures during Global Financial Shocks ......................................22 


\section{INTRODUCTION}

Four years have passed since the bankruptcy of Lehman Brothers marked the beginning of a global storm that has put many advanced economies on the verge of a financial meltdown. Today financial risks continue to loom over the world economy, raising questions about the potential impact of global financial shocks on emerging market economies (EMEs). However, whether these economies are more or less vulnerable to external financial shocks is not obvious. Over the past two decades, most EMEs witnessed significant changes in two critical dimensions that are likely to determine the impact of these global shocks on their domestic economies. On the one hand, most went through a marked process of financial integration with the rest of the world, arguably turning them more sensitive to global financial conditions. ${ }^{1}$ On the other hand, they witnessed marked improvements in key macroeconomic fundamentals, thus making them more resilient to such shocks.

This paper studies the impact of global financial shocks on the domestic output of EMEs, with a focus on the role that financial integration and macroeconomic fundamentals have in mitigating or amplifying such effect. Specifically, the paper makes two contributions: (i) it focuses on the pure effect of external financial shocks by isolating the impact of these events from any contemporaneous trade shocks; and (ii) it examines how the degree of financial integration and the strength of macroeconomic fundamentals interact with these external disturbances either to amplify or mitigate their impact on the economy. For this purpose, we assess the impact of large external financial shocks using a cross-sectional econometric approach based on a quarterly database for 40 emerging market and 9 'small advanced' economies over the period 1990-2010.

This work is related to several branches of literature. First, it relates to the recent literature on decoupling, which has argued that EMEs have become less dependent on (i.e., have 'decoupled' from) the economic performance of advanced economies (see IMF, 2007). While motivated on the remarkable growth performance in EMEs over the past decade despite slow growth in advanced economies, this view seems to have been vindicated during the 2008-09 global crisis, as many EMEs navigated relatively unscathed through what was clearly the most severe global shock in decades. Our paper adds to this literature by disentangling and quantifying the specific mechanisms that may amplify and mitigate the output cost to global shocks.

The paper is also related to a growing literature examining the role of sudden changes in uncertainty - as proxied, for example, by spikes in the VIX index - in driving the business cycle (Bloom, 2009). Uncertainty spikes can have sizeable effects on real activity, through a "wait and see" behavior that amplifies economic cycles. Indeed, such spikes have been shown to induce a collapse in investment and private consumption. Also that such effects are more severe in EMEs than in the United States, possibly due to the role that financial frictions tend to play in EMEse.g., collateral constraints, liquidity shortages, or currency mismatches (see Carrière-Swallow and Céspedes, 2011). Our paper relates to this literature to the extent that the identified effects of global financial shocks on domestic output in EMEs — i.e., spikes in the VIX — may partly arise

\footnotetext{
${ }^{1}$ Of course, increased financial integration may also have brought other benefits (e.g., risk sharing, better international allocation of savings, transfer of financial expertise). These, however, are beyond the scope of this paper.
} 
from heightened uncertainty. Unlike these other papers, however, we aim at disentangling the role of macroeconomic fundamentals and financial integration in amplifying or mitigating the impact of these shocks, rather aiming at assessing the specific role that heightened uncertainty may have.

Finally, our paper relates broadly to several strands of recent literature examining the role of macroeconomic fundamentals in absorbing external shocks and the real effects of sudden stops, and contagion (see for example, Calvo and others, 2004; Calvo and Talvi, 2008; and Ocampo, 2012). Unlike these studies, however, we pay special attention to the role of financial integration and its evolution over time in determining EMEs' vulnerability to exogenous global financial shocks.

Our analysis provides some interesting insights: First, large global financial shocks tend to have a sizeable impact on EMEs output, even after controlling for any associated trade shock (e.g., terms-of-trade or drop in external demand). Second, these shocks have non-linear effects on EME's domestic output which vary with the degree of financial integration with the rest of the world and the strength of macroeconomic fundamentals. In particular, exchange rate flexibility has a prominent role buffering the impact of these shocks, especially for highly financially integrated economies. The strength of the external position (current account balance and external debt) is also found to play a similar role. Third, greater financial integration does not always increase a country's vulnerability to external financial shocks. As a matter of fact the exchange rate regime is critical in determining this relationship: financial integration amplifies global financial shocks in economies with fixed exchange rate regimes, but mitigates them in economies with more flexible regimes. The corollary of these results is that financially integrated economies with strong fundamentals (especially exchange rate flexibility) are better equipped to cope with global financial shocks than countries with weak fundamentals and limited financial linkages.

Our analysis also allows us to assess how the vulnerability of different countries in our sample to an adverse global financial shock varies across regions and time. In particular, simulations of the estimated model - that combine the joint effect of higher financial integration and changing fundamentals to an adverse global financial shock - show that, while still significantly vulnerable, both Latin America and Emerging Asia are less sensitive today to these shocks than in the past. By contrast, Emerging Europe, is found to be more vulnerable nowadays, on account of both a steep process of financial integration, and worsening of fundamentals in some key dimensions turned over the past $10-15$ years.

The rest of the paper is organized as follows: Section II discusses the identification of global financial shocks and the behavior of key global variables during these episodes. Section III documents the evolution of financial integration and key macroeconomic fundamentals across EMEs since 1990. Section IV discusses the econometric methodology, presents its main findings, and reports simulation results to illustrate the changing vulnerability of EMEs to global financial shocks. Finally, Section V concludes with a discussion of the key take-a-ways and avenues for further research. 


\section{RECURRENT EPISODES OF GLOBAL FINANCIAL STRESS}

The S\&P 500 Chicago Board Options Exchange Market Volatility Index (VIX) has gained acceptance as a summary indicator of global uncertainty or financial stress. ${ }^{2}$ According to itand based on a simple statistical analysis that identifies large deviations of the index from its own trend (as in Bloom, 2009) - the world has experienced periods of global financial stress every $2 \frac{1}{2}$ years on average over the past two decades (Figure 1 and Table 1). Whether these shocks originated in advanced economies (e.g., 9/11 or Lehman) or emerging market economies (e.g., the Asian or the Russian crises), their repercussions were global, ${ }^{3}$ and their effects where arguably transmitted to EMEs and small advanced economies through two main channels:

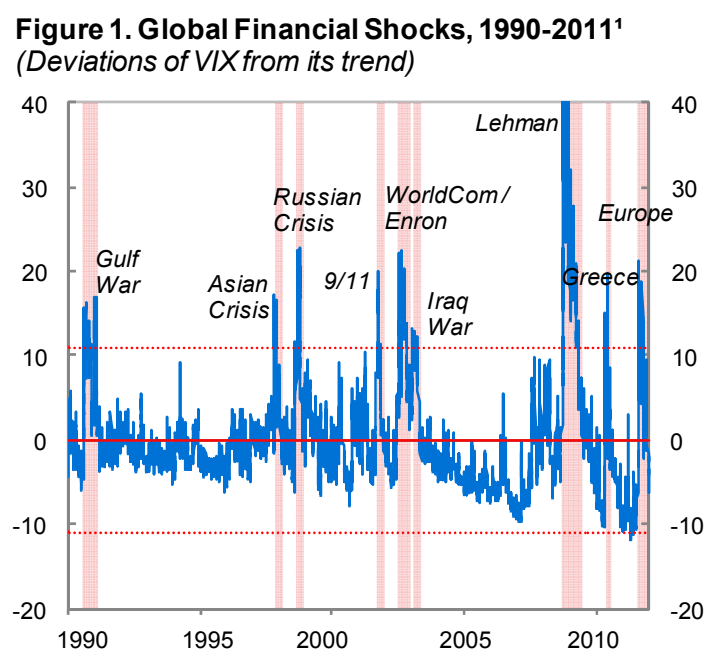

Sources: Haver Analytics; and authors' calculations. ${ }^{1} \mathrm{An}$ episode is identified if the value exceeds its mean by 1.65 standard deviations (as in Bloom, 2009). Episode window starts and ends when the value crosses the one standard deviation threshold.

Table 1. Global Financial Shocks, 1990-20111/

\begin{tabular}{lrrrrrr}
\multicolumn{3}{c}{ Table 1. Global Financial Shocks, 1990-2011 1/ } \\
\cline { 5 - 7 } \multicolumn{1}{c}{ Episode } & \multicolumn{1}{c}{ Start 2/ } & \multicolumn{1}{c}{ Peak } & \multicolumn{1}{c}{ End 2/ } & \multicolumn{2}{c}{$\begin{array}{c}\text { Days with VIX } \\
\text { above: }\end{array}$} \\
\hline Gulf War & $8 / 3 / 90$ & $8 / 23 / 90$ & $1 / 17 / 91$ & 167 & 163 sd \\
Asian Crisis & $10 / 27 / 97$ & $10 / 30 / 97$ & $1 / 9 / 98$ & 74 & 16 \\
Russian Crisis & $8 / 4 / 98$ & $10 / 8 / 98$ & $10 / 28 / 98$ & 85 & 63 \\
9/11 & $9 / 7 / 01$ & $9 / 20 / 01$ & $11 / 5 / 01$ & 59 & 31 \\
Enron \& Iraq War & $7 / 3 / 02$ & $8 / 5 / 02$ & $4 / 7 / 03$ & 278 & 244 \\
Lehman & $9 / 15 / 08$ & $11 / 20 / 08$ & $5 / 27 / 09$ & 254 & 227 \\
Greece & $5 / 6 / 10$ & $5 / 20 / 10$ & $7 / 1 / 10$ & 56 & 23 \\
Europe & $8 / 8 / 11$ & $8 / 8 / 11$ & $11 / 25 / 11$ & 109 & 109 \\
\hline
\end{tabular}

1/Episodes identified based on deviations of the VIXindex from its HP trend (Ravn and Uhlig parameters). An episode is identified if the value of the measure exceeds 1.65 standard deviations.

$2 /$ On the basis of variable being above 1 standard deviation above mean.

2 The exact interpretation of spikes in the VIX is still a matter of debate in the academic literature. Bloom (2009), however, shows that the VIX is strongly correlated with measures of uncertainty, including financial variables. This lends support to its use as a measure of global financial stress. See also Carrière-Swallow and Céspedes (2011).

${ }^{3}$ Kaminsky and Reinhart (2004) study under what conditions financial turbulence originated in certain EMEs spread globally, to other emerging and advanced economies. They argue that these episodes only spreads out when the local shock affects asset markets in one or more of the world's financial centers, otherwise spillovers are confined to countries in the same region. Or to put it differently, for a shock to become systemic it has to reach the financial center. This conclusion supports the choice of the VIX a global shock measure. 
Trade channel: Excluding those episodes linked to geopolitical tensions in the Middle Eastleading to spikes in oil prices-all episodes of global financial shocks were accompanied by sharp falls in commodity prices, possibly reflecting expectations of a slowdown of the world economy and so of the demand for these basic products. Indeed, most episodes also led to softer external demand, as suggested by economic activity indicators of large advanced economies (Figure 2, top panels).

Financial channel: At the same time, these episodes were accompanied by sizeable repricing of sovereign risk - as reflected in the widening of EMBI spreads - and a reversal of capital flows, in some cases very pronounced (Figure 2, bottom panels).

Thus, to varying degrees, EMEs are likely to have been affected both through trade and financial channels during these episodes. In this paper, we focus on the financial dimension - that may also encompass the effect of spikes on uncertainty as discussed before - and their economic impact on EMEs. ${ }^{4}$
Figure 2. Key Variables during Episodes of Global Financial Shocks, 1990-2011

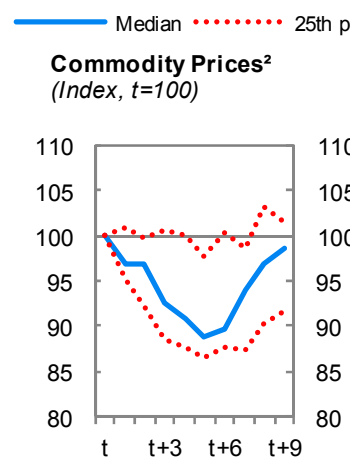

EMBI Global Spreads ${ }^{4}$ (Change relative to $t=0$ )

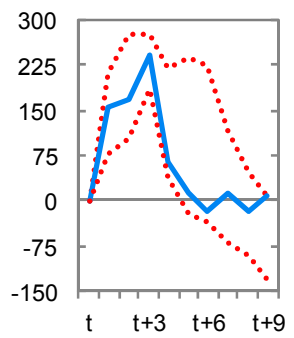

5 th percentile 75th percentile Advanced Markets Industrial Production ${ }^{3}$ (Normalized, $t=0$ )

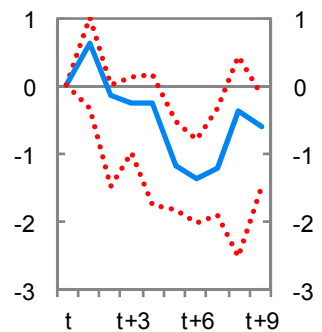

EM Mutual Fund Flows 5 (Cumulative, percent of assets)

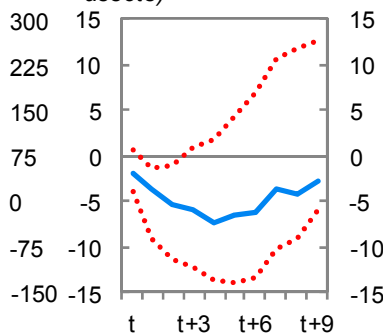

Sources: Haver Analytics; IMF, International Financial Statistics and authors' calculations.

${ }^{1}$ Months reported on horizontal axis. $t=0$ is start of the episode as identified in Figure 3.1. Percentiles across episodes are reported.

${ }^{2}$ Broad IMF commodity price index, in real terms, adjusted for exchange rate valuation effects (see Adler and Sosa, 2011) ${ }^{3}$ Change in cyclical component of industrial production.

Weighted average for the U.S., Japan, Germany, and France. ${ }^{4} \mathrm{EMBI}=$ Emerging Market Bond Index. Excludes Gulf War and Asian crisis events, due to lack of data.

${ }^{5}$ Flows to emerging market (EM) equity and bond mutual funds, in percent of total assets under management. Excludes episodes prior to 2000 due to lack of data.

\footnotetext{
${ }^{4}$ Trade shocks (particularly those arising from commodity price fluctuations) have been subject of analysis in Adler and Sosa (2011) and the Fall 2011 edition of the IMF's Regional Economic Outlook-Western Hemisphere.
} 


\section{FinanCial InTEgRation AND ECONOMIC Fundamentals: ACTING IN OPPOSING DIRECTIONS?}

We conjecture that the impact of global financial shocks on EMEs depends primarily on two main factors (Figure 3):

Figure 3. Financial Openness, 1990-2010

On the one hand, a country's degree of financial integration with the rest of the world is likely to influence its vulnerability to external financial shocks. While financial integration is a somewhat elusive concept - and has been studied from different angles — one would expect that, other things equal, a higher degree of integration would increase domestic sensitivity to these shocks. ${ }^{5}$ To capture this, we focus on the stock of foreign assets and liabilities, relative to GDP, as a measure of financial integration ${ }^{6}$ as this indicator is likely to capture both the degree of arbitrage (spillover) between external and domestic financial markets, as well as the potential magnitude of the economic impact of external shocks on the domestic economy.

On the other hand, a country's strength of economic fundamentals is also likely to buffer or amplify the impact of external shocks. Strong fundamentals can prevent capital outflows in the first place (as investors would be less concerned about credit worthiness) but can also play a role in allowing the economy to adjust more easily to a given shock (for example, by providing more room to undertake countercyclical policies - e.g.; lowering interest rates, letting the exchange rate depreciate or using fiscal policy to stabilize domestic demand).

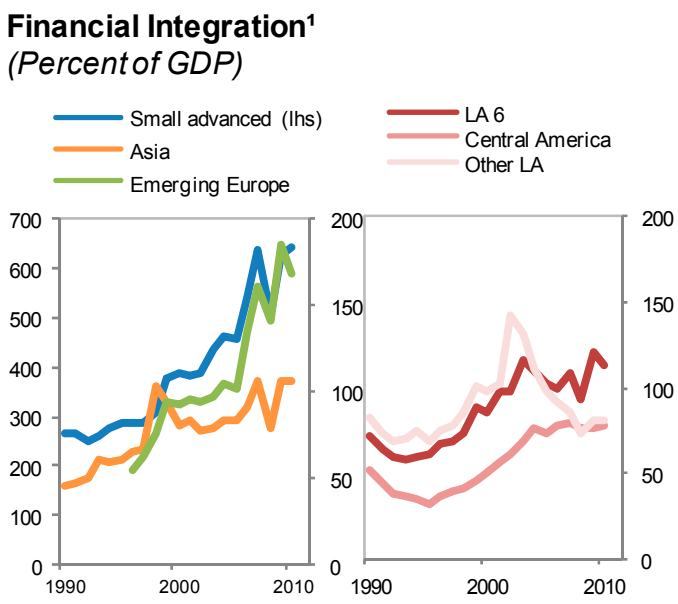

Capital account restrictions (Chinn-Ito Index ${ }^{2}$ )

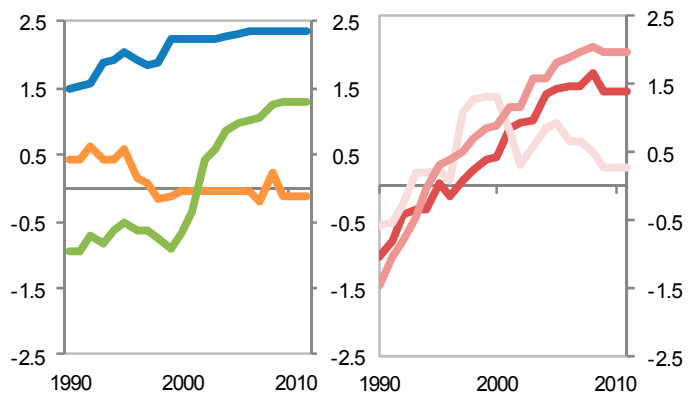

Source: Updated and extended version of the Lane and Milesi-Ferretti (2007) database; updated version of Chinn-Ito (2008); and authors' calculations.

${ }^{1}$ Foreign assets plus foreign liabilities net of international reserves and official external debt.

${ }^{3}$ The index is based on the binary dummy variables that codify the tabulation of restrictions on cross-border financial transactions reported in the IMF's Annual Report on Exchange Arrangements and Exchange Restrictions (AREAER). Higher values of the index are indicative of a country's greater degree of capital account openness. Simple averages.

\footnotetext{
${ }^{5}$ Financial integration may have other potential and positive side effects-e.g., risk sharing or higher long-term growth - which are not considered in our analysis.

${ }^{6}$ We also explore a similar measure that excludes international reserves and official external debt, as these components are unlikely to be channels of transmission of external shocks. On the contrary, these components of the international investment position tend to be counter-cyclical. Stylized facts, and econometric results, however, do not change significantly with this alternative measure.
} 
To varying degrees, EMEs across the board have experienced a marked transformation over past two decades in these two fronts, potentially changing its vulnerability to global shocks.

Figure 4. EMEs and SAEs Financial Openness, 2010

Capital account restrictions', 2009 (Chinn-Ito Index ${ }^{2}$ )

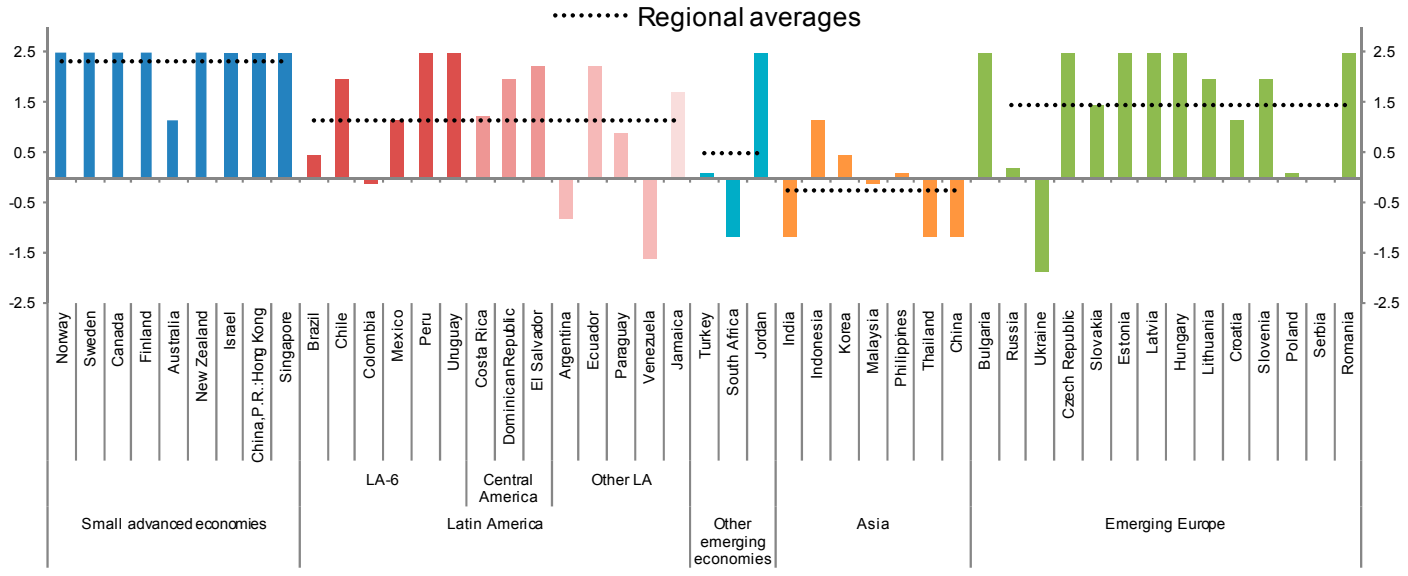

Source: Chinn-Ito (2006). Available at; http://web.pdx.edu/ ito/Chinn-Ito website.htm

Note: Higher values of the in dex are indicative of a country's greater degree of capital account openness.

1 Simple averages.

2 The index is based on the binary dummy variables that codify the tabulation of restrictions on cross-border financial transactions

reported in the IMF's Annual Report on Exchange Arrangements and Exchange Restrictions (AREAER).

Financial integration ${ }^{1,2}, 2010$

(Percent of GDP)

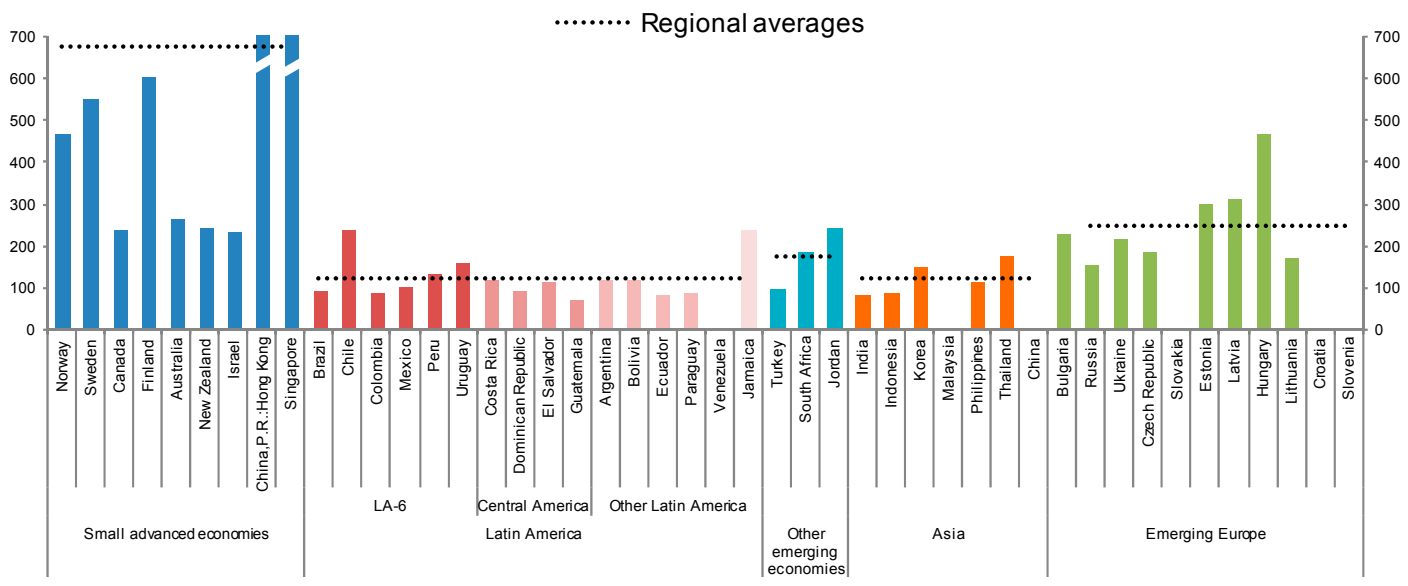

Source: Lane and Milessi Ferretti (2007).

Note: Hong Kong and Singapore values exceed th ose of the reported scale. Their corresponding values are 2261 and 1241 ,

respectively.

1 Foreign Asset plus foreign liabilities as percentof GDP

${ }^{2}$ Simple averages.

The most prominent transformation has been the increase in financial integration with the rest of the world, mostly resulting from a gradual process of financial liberalization and withdrawal of restrictions on international capital movements, particular during the 1990's, as shown by the 
Chinn and Ito index of capital account openness (Figure 3 and 4). This is visible in Latin America $^{7}$ and Emerging Asia, and even more so in Emerging Europe (and to an even greater extent in small advanced economies).

At the same time, many emerging market economies have witnessed a gradual strengthening of its economic fundamentals in a number of dimensions, particularly on the external and fiscal fronts, during the past two decades (Figure 5 and 6). This has been evident in Latin America and Emerging Asia, but less so in Emerging Europe.

Since progress in these two dimensions have opposing and non-trivial implications for the transmission of global financial shocks to EMEs, assessing a country's vulnerability to them - and whether it has increased or declined over time - requires a multivariate econometric approach that appropriately captures and quantifies the importance of these two opposing forces.

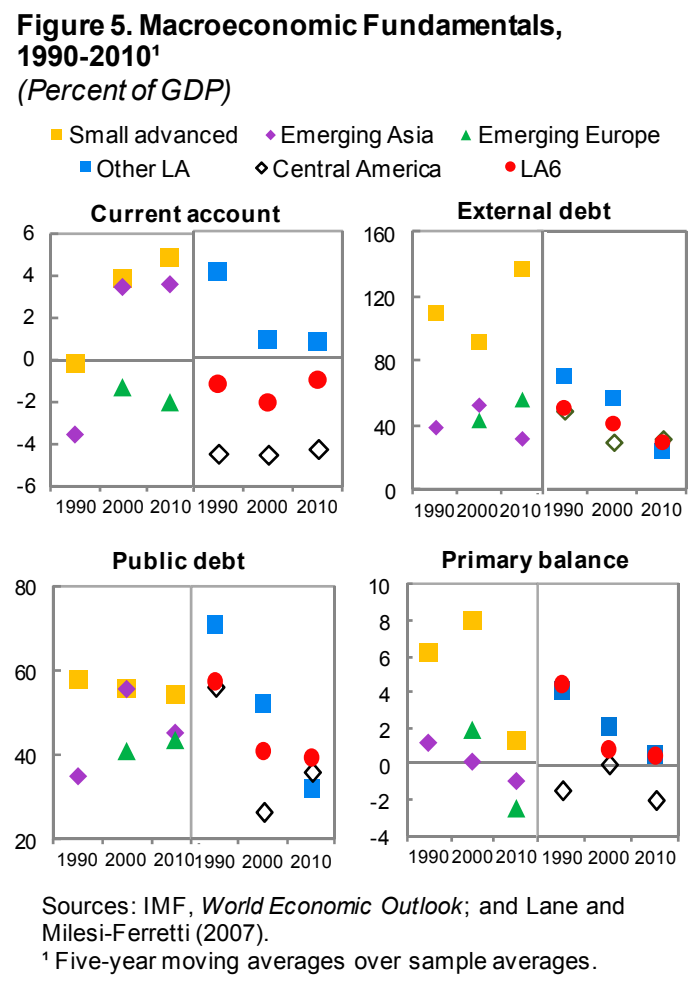

\section{The IMPACT OF GLOBAL FinANCIAL SHOCKS}

\section{A. Sample, Data, and Econometric Approach}

To quantify the impact of large external financial shocks on domestic output we undertake a cross-sectional econometric approach based on quarterly observations for a sample of 40 EMEs and 9 'small' advanced economies, during 7 episodes of global financial shocks (measured by sizeable spikes in the VIX index, as defined in Figure 1). Of the 9 episodes identified earlier, those of Enron and the Iraq War are treated as one, given their close proximity. Similarly, the 2011 event associated with the European crisis is dropped due to insufficient observations (only GDP data up to 2011Q4 was available on a comprehensive basis). ${ }^{8}$

\footnotetext{
${ }^{7}$ Within Latin America, this trend has not been homogenous across different economies. Countries in the LA6 group (Brazil, Chile, Colombia, Mexico, Peru and Uruguay) and Central America countries have led the pace of integration within the region, while other countries in South America have moved in the opposite direction, particularly over the past decade.

${ }^{8}$ It is important to highlight that, in contrast to the majority of studies, which rely on annual data, our analysis is based on quarterly data, allowing us to measure more precisely the output costs of global financial shocks (see Annex Table A1). For most countries the constructed dependent variable uses quarterly GDP data. In some instances, however, quarterly GDP series are extended by chaining them with variance-adjusted indicators of economic activity or industrial production. See Annex Table A1for details.
} 
Figure 6. Key Macroeconomic Fundamentals in EMEs and SAEs, 2010 versus 2000

Current Account Balance

(Percent of GDP)

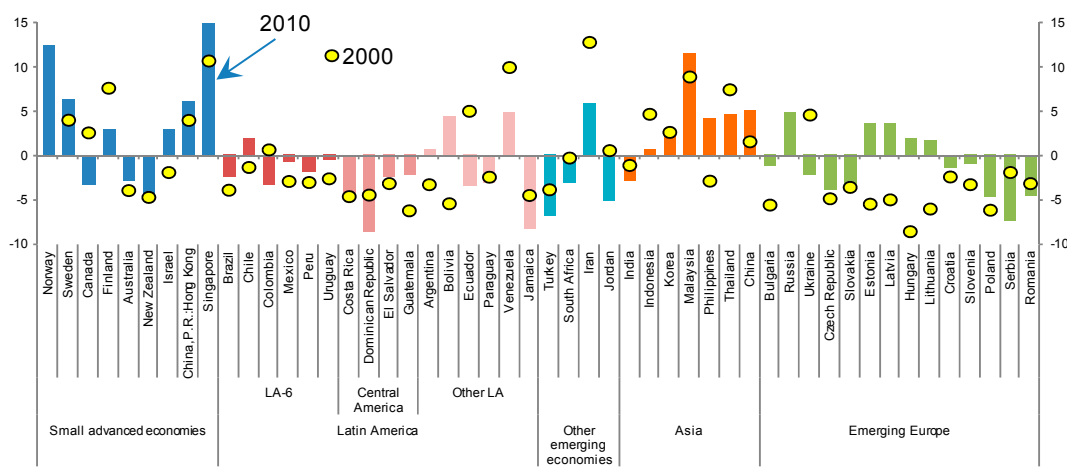

External Debt

(Percent of GDP)

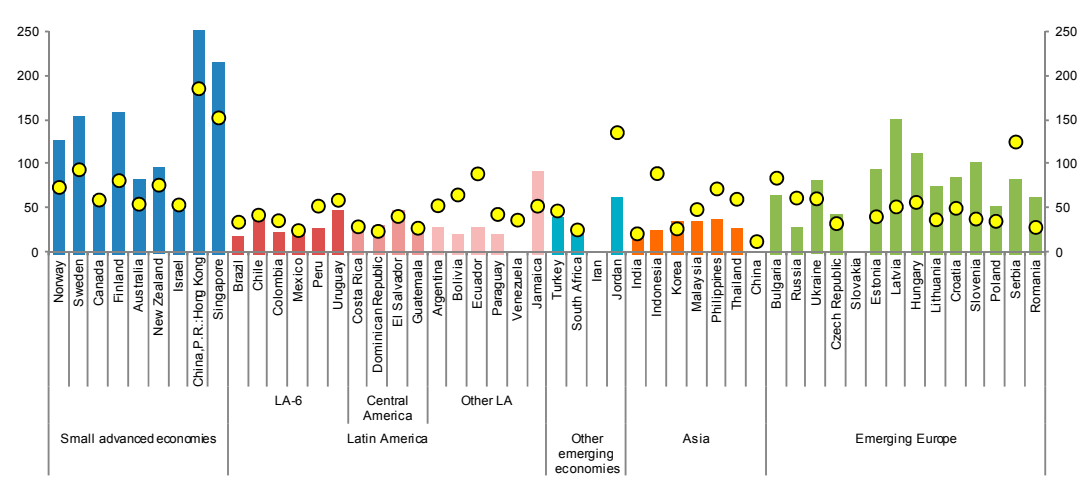

Source: IMF International Financial Statistics and authors' cal culations.
Public Debt

(Percent of GDP)

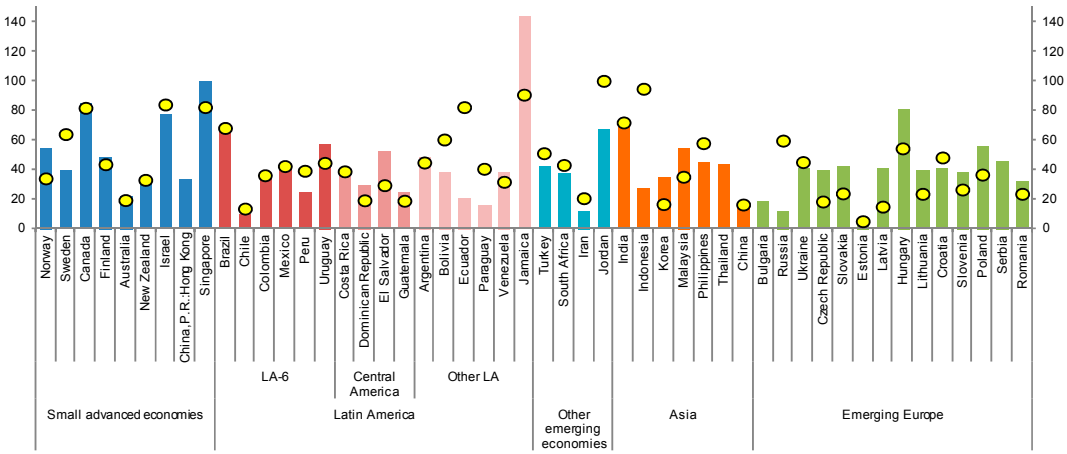

Primary Balance

(Percent of GDP)

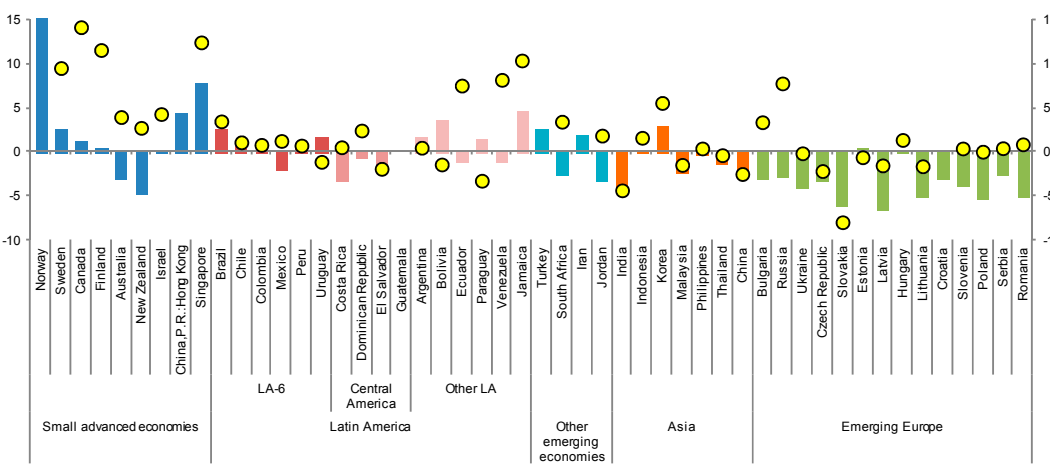


The econometric analysis has three key features:

First, our dependent variable measuring output performance captures both the depth and duration of each individual episode $j$ (Figures 7 and 8). Specifically, we compute the cumulative change in the cyclical component of output $\left(Y_{i, \mathrm{j}}\right)$ - estimated using a standard Hodrick-Prescott filterover the duration of the episode and the following two quarters (as long as there is no overlap with a subsequent event), in order to capture possible lagged effects of the shock.

$$
\mathrm{Y}_{\mathrm{i}, \mathrm{j}}=\sum_{\mathrm{t} \in \mathrm{j}}\left(\frac{\mathrm{y}_{\mathrm{i}, \mathrm{t}}-\mathrm{y}_{\mathrm{i}, \mathrm{t}}^{\mathrm{p}}}{\mathrm{y}_{\mathrm{i}, \mathrm{t}}^{\mathrm{p}}}\right) * 100
$$

A glance at the distribution of our output loss measure suggests that performance varied significantly, both across episodes and countries, with some economies displaying sizeable output losses, while others showing positive growth during these events. The 2008-09 event that followed the bankruptcy of Lehman Brothers deserves a special attention, not only because of the severity of the shock, but also because despite the wide dispersion of outcomes, all countries experienced notorious output losses. Annex 1 provides an alternative perspective, showing the growth dynamics around these episodes.

Figure 7. Output Performance during Global Financial Shocks, 1990-2011

(cumulative deviations from potential output, in percent of annual GDP)
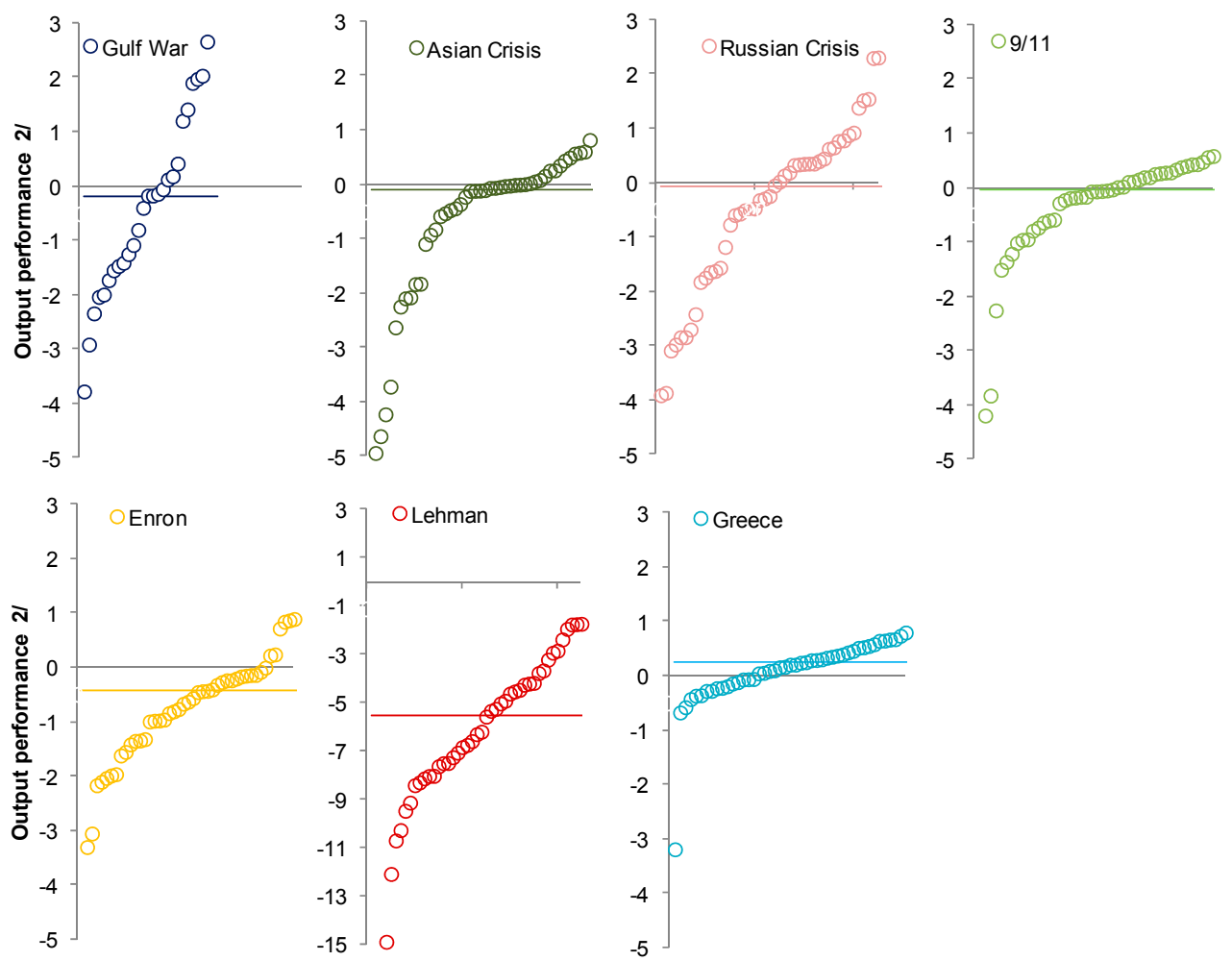

Source: Authors' calculations.

$1 /$ Countries are ordered from most to least affected, for each episode. Scales are the same across charts, except for the Lehman event. $2 /$ Cumulative deviations from trend output (HP filter) in percent of annual GDP. 
Second, we choose a specification that disentangles the link between domestic output performance and global financial shocks (measured by the VIX) after controlling for any associated effect arising through trade channels. In the absence of comprehensive (countryspecific) data on terms of trade and external demand, that would allow to measure such trade shocks more precisely, we rely on a proxy variable that measures the cumulative loss of exports (in percent of trend) during the episode. Resembling the measure of output performance, this variable captures both the depth and duration of the trade shock, during each event. A weakness of this measure is that it is not entirely exogenous, and may lead to 'over-controlling'. For this reason, and to check the robustness of the results, regressions are also run using available series of terms-of-trade and world GDP instead of exports (which proxy for exogenous trade prices and external demand). Results remain qualitatively and quantitatively unchanged.

Third, the specification allows for the financial shock to interact with the country's degree of financial integration (defined as total foreign assets plus total foreign liabilities, in percent of GDP $)^{9}$ as well as with measures of economic fundamentals. In this manner we are able to study the amplification or mitigation effect of these country features in the face of a global financial shock. Moreover, we allow for interaction effects between country fundamentals and financial integration.
Figure 8. Output Performance during Global Financial Shocks, 1990-2011'

(Cumulative)


Post-Lehman Episode (Greece) ${ }^{3}$

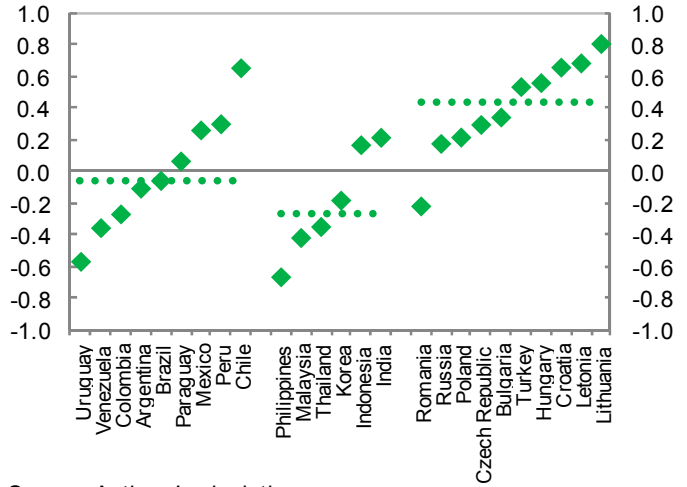

Source: Authors' calculations.

${ }^{1}$ Cumulative change in the cyclical component of GDP, in percent of (potential) GDP. Dotted lines reflect regional medians. ${ }^{2}$ Average of different episodes, excluding cases of identified idiosyncratic events: Asian countries (1997), Russia (1998), Brazil (2002), and Uruguay (2001-02).

${ }^{3}$ Greece event of May 2010. The European episode of mid-2011 is not included, because comprehensive GDP data were not available at the time of publication.

\footnotetext{
${ }^{9}$ The measure is constructed with data from the updated and extended version of Lane and Milesi-Ferretti (2007) database. Econometric results also hold for a measure of financial integration that strips holdings of international reserves, as well as official loans. Such adjustment is meant to better capture those assets and liabilities that would be sensitive to global shocks.
} 
Thus, the benchmark model is:

$$
\mathrm{Y}_{\mathrm{i}, \mathrm{j}}=\beta_{0}+\beta_{1} \operatorname{Exp}_{\mathrm{i}, \mathrm{j}}+\beta_{2} \mathrm{GFS}_{\mathrm{j}}+\beta_{3} \mathrm{FI}_{\mathrm{i}, \mathrm{j}} * \mathrm{GFS}_{\mathrm{j}}+\boldsymbol{\beta}_{4}^{\prime} \mathbf{X}_{\mathrm{i}, \mathrm{j}} * \mathrm{GFS}_{\mathrm{j}}+\boldsymbol{\beta}_{5}^{\prime}\left(\mathbf{X}_{\mathrm{i}, \mathrm{j}} \mathrm{FI}_{\mathrm{i}, \mathrm{j}}\right) * \mathrm{GFS}_{\mathrm{j}}+\varepsilon_{\mathrm{i}, \mathrm{t}}
$$

Where $i$ and $j$ denote country and episode respectively; $\operatorname{Exp}_{i, j}$ is the cumulative change in de-trended exports (in percent of trend); $G F S_{j}$ is the global financial shock, computed as the average monthly VIX times the length of the episode, in months; $\mathbf{X}_{\mathrm{i}, \mathrm{j}}$ is the vector of country fundamentals, evaluated at the beginning of each episode; and $F I_{i, j}$ denotes financial integration.

Broadly speaking, $\beta_{2}$ captures the direct effect of the global financial shock, while $\beta_{3}$ and $\beta_{4}$ captures the interaction effect of the global shock with financial integration and fundamental respectively (i.e., the amplification or mitigation effect). Finally, the last term (with coefficient $\beta_{5}$ ) is introduced to capture the fact that the role of fundamentals in the face of a global shock may not be independent of the degree of financial integration. It is important, however, to keep in mind that, in quantifying the role of fundamentals and financial integration, one must take the total effect of the shock into account. More precisely, under this specification, the marginal effect of a global financial shock (equivalent to a one-point increase in the VIX) is given by:

$$
\frac{\partial Y_{i, j}}{\partial G F S}=\beta_{2}+\beta_{3} * \mathrm{FI}_{\mathrm{i}, \mathrm{j}}+\boldsymbol{\beta}_{4}^{\prime} \mathbf{X}_{\mathrm{i}, \mathrm{j}}+\boldsymbol{\beta}_{5}^{\prime}\left(\mathbf{X}_{\mathrm{i}, \mathrm{j}} \mathrm{FI}_{\mathrm{i}, \mathrm{j}}\right)
$$

And the amplification effect of a fundamental (x), included in $\mathbf{X}$, is given by:

$$
\frac{\partial^{2} Y_{i, j}}{\partial \mathrm{GFS} \partial \mathrm{x}}=\beta_{4, \mathrm{x}}+\beta_{5, \mathrm{x}} * \mathrm{FI}_{\mathrm{i}, \mathrm{j}}
$$

The following country fundamentals are explored: ${ }^{10}$

- $\quad$ Exchange rate flexibility, as captured by the 'de facto' exchange rate regime classification of Ilzetzki, Reinhart and Rogoff (2008). The variable, based on the coarse classification, excludes those regimes classified as freely falling or dual markets with missing parallel market data. It is also normalized to range from 0 to 1 , with 1 being a freely floating regime and 0 a peg or similar regime.

- External sustainability measures, as reflected in current account balance, external debt, net foreign assets and international reserves, all in percent of GDP.

- $\quad$ Fiscal position measures (public debt and primary balance, in percent of GDP).

- Deposit dollarization, from Levy Yeyati's database, augmented to extend country and time coverage, based on IMF country staff reports and country desk information.

\footnotetext{
${ }^{10}$ Other country characteristics that may also be relevant, like exchange rate misalignment, measures of strength of the financial system, financial regulation, macro-prudential policies, etc. are not included in the econometric exercise due to data limitations.
} 
A possible shortcoming of the specification (and its selection of fundamentals) is that it does not explore the role of policy responses - which may have varied over time and countries. However, it is important to keep in mind that policy space at the time of a shock is normally determined by the initial conditions (countercyclical fiscal or monetary policy would normally be possible only if fiscal solvency is not an issue and the monetary/exchange rate framework is sufficiently flexible at the time of the shock). Hence, it is likely that policy response measures would be correlated with some of the measures of country fundamentals already considered in our specification.

Simple bi-variate analysis of the data, using cumulative frequency distributions, highlights the importance of some of these country features, particularly when the financial shock is of large magnitude (Figure 9). Specifically we find that:

- A low degree of exchange rate flexibility appears to be associated with sharp economic contractions.

- This is also the case for low current account balance, low net foreign assets and highly dollarized economies.

- Interestingly, in this simple bi-variate analysis, financial integration or the level of international reserves appear to have a muted role.

Although these simple patterns may provide some insights of the relevance of some variables vis-a-vis others, they should be interpreted with caution, as they may reflect simple correlations with other variables.

Figure 9. Output Performance and Fundamentals during Global Financial Shocks, 1990-2011 1/ (cumulative density function for lower and upper half of sample, based on fundamentals)
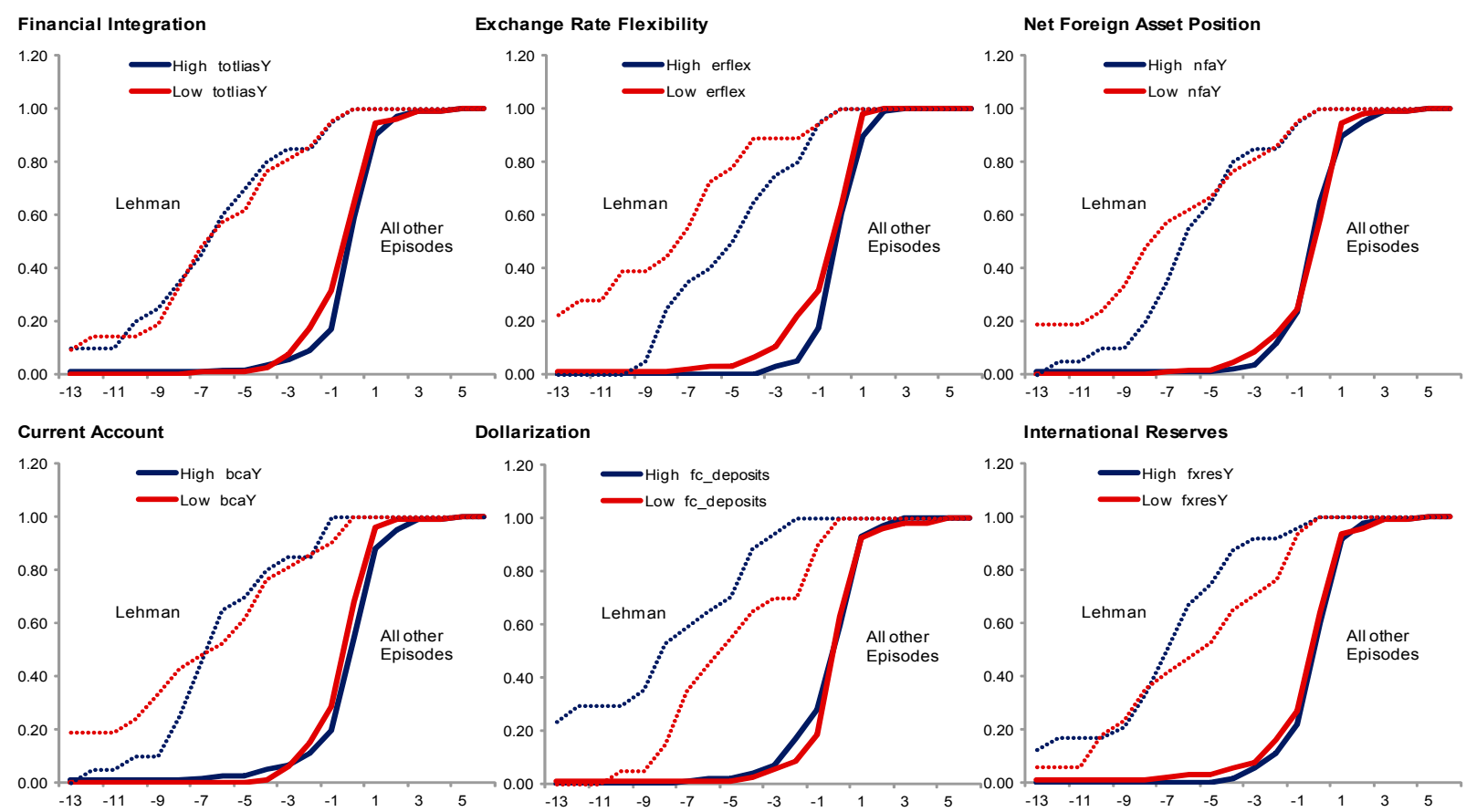

Source: Authors' calculations.

1/Cumulative change in cyclical component of output (based on HP filter), in percent of annual GDP. 


\section{B. Cross-Sectional Results}

We explore a number of specifications of the cross-sectional multivariate setting described above to get a sense of the role that individual variables have in amplifying or mitigating the impact of financial shocks. For simplicity we start with a basic specification that reports the effect of the VIX on our measure of output. From there on, all specifications control for trade effects and include different combinations of macroeconomic fundamentals and their interaction with financial integration, depending on their statistical significance. A summary with the most relevant results is reported in Table 2 (See also Annex Tables A2-A3).

Table 2. Main Results of Cross-Section Estimation ${ }^{1}$

\begin{tabular}{|c|c|c|c|}
\hline \multirow[t]{2}{*}{ Dependent Variable: } & \multicolumn{3}{|c|}{ Output Performance $^{2}$} \\
\hline & Basic model & \multirow{2}{*}{ Main } & \multirow{2}{*}{$\begin{array}{c}\begin{array}{c}\text { Robust- } \\
\text { ness }\end{array} \\
\end{array}$} \\
\hline Variable & & & \\
\hline VIX & $\begin{array}{cc}-0.176^{* * *} & -0.047^{* * *} \\
(0.018) & (0.017)\end{array}$ & $\begin{array}{c}0.010 \\
(0.028)\end{array}$ & $\begin{array}{l}0.008 \\
(0.034)\end{array}$ \\
\hline Trade channel & $\begin{array}{c}0.117^{* * *} \\
(0.019)\end{array}$ & $\begin{array}{c}0.113^{\star \star \star} \\
(0.020)\end{array}$ & \\
\hline Terms of trade & & & $\begin{array}{l}7.637^{* *} \\
(3.553)\end{array}$ \\
\hline World GDP & & & $\begin{array}{c}0.945^{\star \star *} \\
(0.207)\end{array}$ \\
\hline \multicolumn{4}{|l|}{ Interaction of VIX with: } \\
\hline Financial integration & & $\begin{array}{c}-0.077+ \\
(0.049)\end{array}$ & $\begin{array}{c}-0.123^{* *} \\
(0.049)\end{array}$ \\
\hline Current account balance & & $\begin{array}{l}0.001+ \\
(0.001)\end{array}$ & $\begin{array}{l}0.001 \\
(0.001)\end{array}$ \\
\hline Exchange rate flexibility & & $\begin{array}{c}-0.096^{* *} \\
(0.046)\end{array}$ & $\begin{array}{c}-0.117^{* *} \\
(0.050)\end{array}$ \\
\hline External debt & & $\begin{array}{c}-0.000+ \\
(0.000)\end{array}$ & $\begin{array}{l}-0.000 \\
(0.000)\end{array}$ \\
\hline \multicolumn{4}{|c|}{ Interaction of VIX with financial integration and: } \\
\hline Exchange rate flexibility & & $\begin{array}{c}0.190^{* * *} \\
(0.070)\end{array}$ & $\begin{array}{l}0.235^{\star * *} \\
(0.074)\end{array}$ \\
\hline Constant & $\begin{array}{cc}15.757^{* * *} & 4.015^{\star *} \\
(1.756) & (1.619)\end{array}$ & $\begin{array}{c}3.229^{\star} \\
(1.674)\end{array}$ & $\begin{array}{l}4.976^{* * *} \\
(1.819)\end{array}$ \\
\hline Observations & 337 & 268 & 268 \\
\hline$R$-squared & 0.418 & 0.641 & 0.571 \\
\hline $\mathrm{F}$ & 68.37 & 23.94 & 18.98 \\
\hline
\end{tabular}

Results suggest that exchange rate flexibility is fundamental in buffering large global shocks, while higher financial integration, current account deficits and external debt, tend to 'amplify' them. Interestingly, and despite our priors, a number of variables were found to have a muted effect. International reserve buffers were found to have no statistically significant role in buffering global shocks. In the case of fiscal variables, we failed to find any significant role for debt levels. ${ }^{11}$ Although the primary fiscal balance was found to play a mitigating role-a stronger position mitigates the impact of the shock, it statistical significance disappeared when other

\footnotetext{
${ }^{11}$ Certainly, it is possible that the limited information content that can be extracted from a simple debt-to-GDP ratio in assessing credit worthiness may be behind the lack of significance of debt levels in our regressions.
} 
fundamentals were included, with no doubt suggesting a strong cross-correlation. Finally, the degree of dollarization did not appear to be significant either. ${ }^{12}$

Recall that the amplification effect of a fundamental (x) is given by Eq. (3). To illustrate such effect, we use the estimated coefficients to obtain the predicted impact of a global financial shock (measured as a 10-point increase in the VIX) for different degrees of financial integration and fundamentals (Figure 10).

Figure 10. Macro Fundamentals and the Impact of Global Shocks ${ }^{1}$
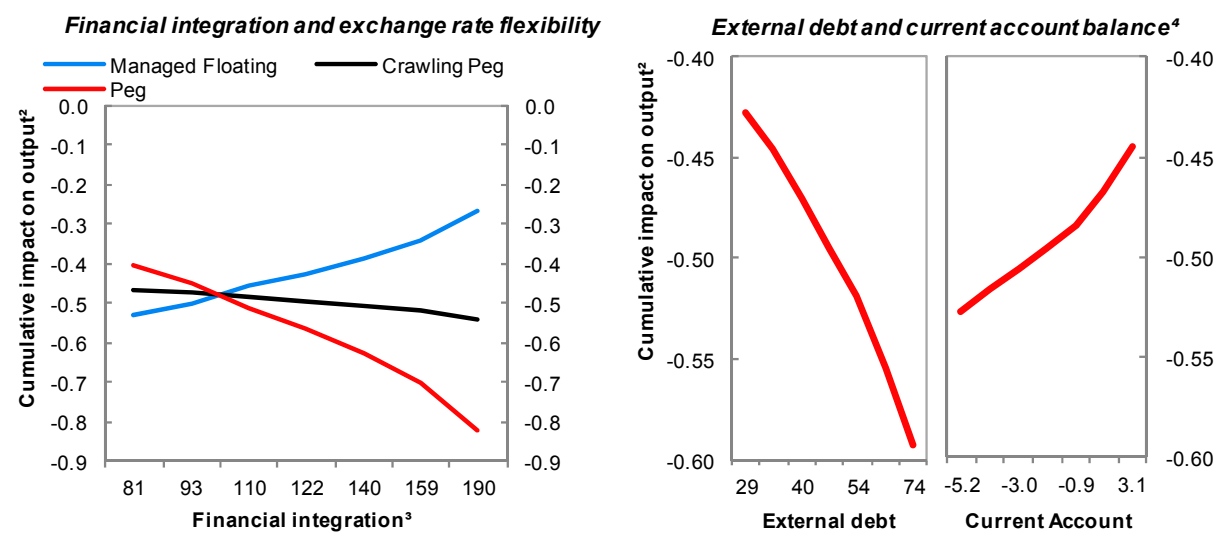

Source: IMF staff calculations

${ }_{1}$ Impact of 10-point VIX shock for different levels of financial integration and fundamentals (other variables unchanged, at median EM value).

${ }^{2}$ Cumulative deviations from trend output in percent of trend.

${ }^{3}$ Total foreign assets plus total foreign liabilities, as percent of GDP. Reported levels correspond to deciles 20-80.

${ }^{4}$ Percent of GDP. Levels correspond to deciles $20-80$.

This shows that:

- For the median EM - with a de facto crawling peg - higher financial integration tends to increase its vulnerability to global financial shocks.

- The role of financial integration in mitigating or amplifying financial shocks, however, greatly depends on the country's exchange rate regime. That is, greater financial integration amplifies the shock under fixed rate regimes but mitigates it under floating regimes. ${ }^{13}$

- At the same time, for most levels of integration, greater exchange rate flexibility reduces the output cost of the global shock. Such mitigation effect is particularly pronounced for high levels of financial integration.

\footnotetext{
${ }^{12}$ Arguably the measure fails to properly capture the extent of currency mismatches in the financial system. Unfortunately, comprehensive data on currency mismatches at the quarterly frequency is not available.

${ }^{13}$ A possible interpretation is that closer financial ties with the rest of the world can help mitigate financial shocks by keeping lines of credit open during these events, provided that the more pro-cyclical (e.g., speculative) flows can be mitigated with an appropriate degree of exchange rate floating.
} 
As expected, larger current account deficits make a country more vulnerable, although the effect is of small magnitude.

- Similarly, high levels of external debt make a country more vulnerable to financial shocks, irrespective of the level of financial integration.

Overall, these results support the notion that financially integrated EMEs with strong fundamentals (especially exchange rate flexibility) are better equipped to cope with global financial shocks than countries where fundamentals are weak or that have fewer financial linkages. Although not analyzed in detail here - mainly due to data limitations - the buffering effect provided by strong fundamentals probably operates in two ways: first, by mitigating capital outflows if an adverse global shock were to occur; and second, by lowering the economic impact of any resulting capital outflows. Some preliminary evidence of the importance of the first effect is discussed in IMF (2012).

\section{ASSESSing Vulnerabilities: Simulation ANALysis}

Finally, we make use of the benchmark model to determine the estimated impact of different financial shocks witnessed in the past two decades across different regions (Figure 11). Specifically, the simulations take as input the values of economic fundamentals and financial integration corresponding to 1997 (right before the Asian crisis), 2008 (right before Lehman) and 2010 (right before Greece's event). This exercise unveils how the degree of vulnerability of different regions has diverged over time. While Latin America and Emerging Asia has seen a gradual improvement (becoming less sensitive to these shocks), particularly since 1997, Emerging Europe has systematically moved in the opposite direction..$^{14}$ As a result, while the estimated impact of a 10 point VIX shock on Latin America and Asia is today around 0.34 percentage points of GDP, the impact on Emerging Europe reaches about 0.57. To give a sense of magnitudes, these estimates imply that a Lehman-type event (with an average 40-point increase in the VIX over a year) would have an

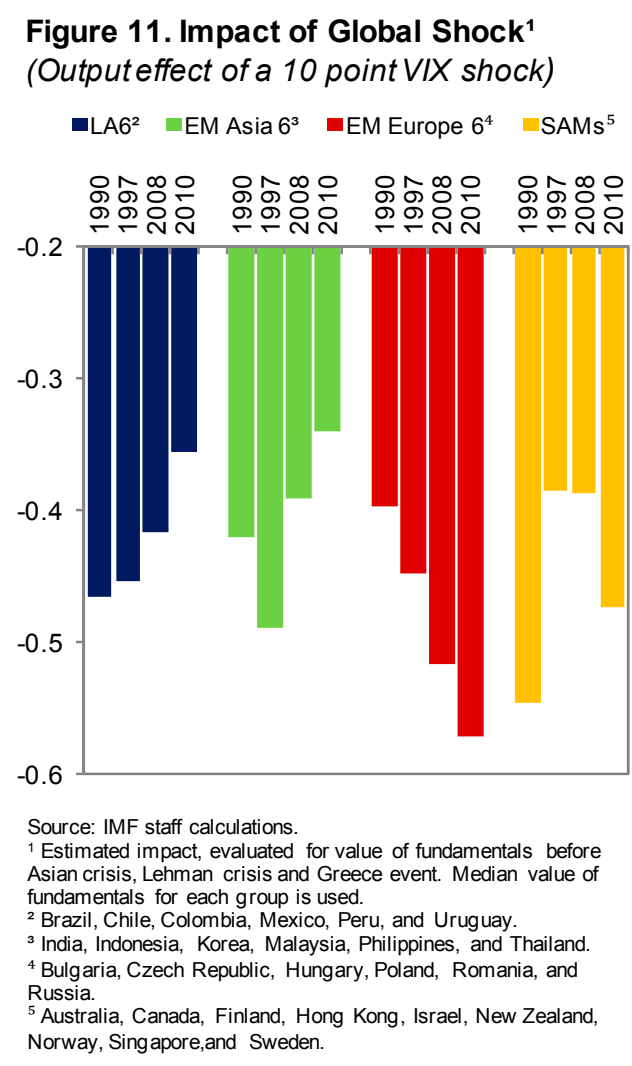

\footnotetext{
${ }^{14}$ While the results on Emerging Europe for the period 1990-2008 are consistent with the well-know buildup of vulnerabilities during this period, a further increase in vulnerability since 2008 may seems at odds with the adjustment efforts seen in many of these economies after the Lehman crisis. This result reflects the fact that our measure of financial integration shows further increases for Eastern Europe, mainly on account of a fall in the denominator (Nominal GDP in foreign currency).
} 
impact equivalent to about 1 1/4 percent of GDP loss in Asia and Latin America, and 21/4 of GDP in Emerging Europe, even after controlling for the associated external trade shock.

These results suggest that improvements in fundamentals over the past 20 years in Latin America and Asia have more than offset the potentially greater vulnerability arising from increased financial integration. In Emerging Europe, on the other hand, both fundamentals (identified as relevant by the econometric exercise) and financial integration have moved in the direction of making the region more vulnerable to global financial shocks.

\section{Conclusions}

Emerging market economies continue to be vulnerable to large global financial shocks, as made evident by the behavior of capital flows in and out of these economies during periods of global financial stress. However, and despite its increasing degree of financial integration, such vulnerability appears to have declined over time for some regions (Latin America and Asia), reflecting to a large extent marked improvements in fundamentals. A key factor determining these effects in many of these economies, particularly in Latin America, has been the progress towards greater exchange rate flexibility which, we find mitigate the impact of adverse financial shocks, particularly in highly financially integrated economies. Countries in both regions have also made improvements in external sustainability (current account and external debt), a key dimension determining the impact of financial shocks. Overall, these results support the notion that financially integrated emerging economies with strong fundamentals (especially exchange rate flexibility) are better equipped to cope with global financial shocks than countries where fundamentals are weak or that have fewer financial linkages. Of course, this does not make them immune to adverse shocks, but at least may help them sail more safely over global financial waves. 


\section{References}

Adler, Gustavo and Sebastian Sosa; 2011; "Commodity Price Cycles: The Perils of Mismanaging the Boom”, IMF Working Paper No. 11/283 (Washington: International Monetary Fund).

Bloom, Nicholas; 2009; “The Impact of Uncertainty Shocks," Econometrica, Vol. 77, No 3, May, 2009.

Carriere-Swallow, Yan, and Luis Felipe Cespedes; 2011; "The Impact of Uncertainty Shocks in Emerging Economies," Documento de Trabajo N 646, November 2011. Banco Central de Chile.

Calvo, Guillermo A., Alejandro Izquierdo and Luis F. Mejia (2004), "On the Empirics of Sudden Stops: The Relevance of Balance -Sheet Effects", NBER Working Paper No. 10520 (Cambridge, MA, USA).

Calvo, Guillermo and Ernesto Talvi, 2005, "Sudden stop, financial factors and economic collapse in Latin America: learning from Argentina and Chile," NBER Working Paper 11153, February.

International Monetary Fund, 2011, Regional Economic Outlook: Western HemisphereShifting Winds, New Policy Challenges (Washington: October).

, 2012, Regional Economic Outlook: Western Hemisphere-Rebuilding Strength and Flexibility (Washington: April).

Ocampo, Jose, 2012, "Balance of Payments Dominance: Its Implications for Macroeconomic Policy," Mimeo School of International and Public Affairs and Fellow of the Committee on Global Thought at Columbia University.

Kaminsky, Graciela and Carmen Reinhart, 2003, "The Center and the Periphery: The Globalization of Financial Turmoil," in Carmen M. Reinhart, Carlos A. Végh and Andres Velasco (eds.), Money, Crises, and Transition: Essays in Honor of Guillermo Calvo. Cambridge, MA: The MIT Press, 2008. 


\section{Appendix. Financial Pressures During Episodes of Global Financial Shocks}

To gauge how large financial shocks may have affected different regions, we construct a measure of exchange rate market pressure and study its behavior during these episodes. The index captures changes in central bank's net foreign assets and in the nominal exchange rate vis-à-vis the U.S. dollar. As expected, its behavior shows that most emerging market (and some small advanced) economies tend to experience depreciating pressures, in times quite sharply, on their currencies during episodes of global financial shocks (identified by VIX spikes). More interestingly, the relative performance of different regions appears to have changed over time. Most notable is the case of Latin America, which appears, on average, to have been among the most affected regions in the past but not in recent events. ${ }^{15}$
Exchange Rate Pressures during Financial Shocks, 1990-2011 1/ (exchange rate market pressure index, medians)

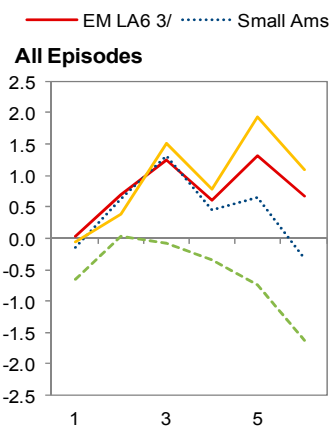

--.-EM ASIA6 2/ —— EM EUR6 4/ Pre-Lehman Episodes

Lehman

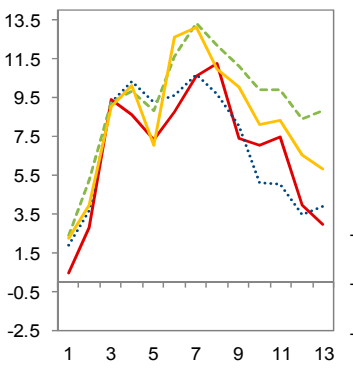

Post-Lehman Episodes 5/

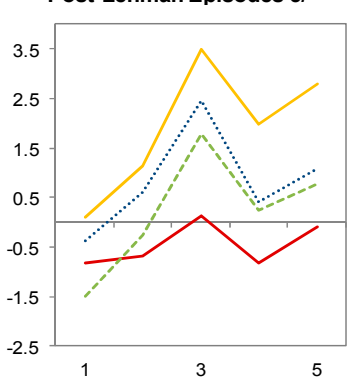

Source: IMF staff calculations.

1/ Median across countries and episodes, excluding 'idiosyncratic' crises. 1/Median across countries and episodes, excluding 'idiosyncratic' crises 2/ Excludes Asian Crisis (1997).

3/ Excludes 2002 Brazilean (Lula) crisis.and (2001-02) Uruguayan crisis (Argeniina shock)

4/ Excludes Russian crisis (1998)

5/ Includes Greece (2010) and Europe (2011)

${ }^{15}$ A caveat is that this measure may also reflect the effect of trade shocks (through their impact on the current account). 


\section{AnNeX 1}

Key Global Variables during Global Financial Shocks, 1990-20111/

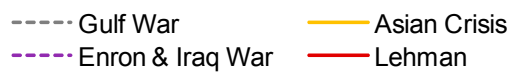

Commodity Prices 2/

$(t=100)$

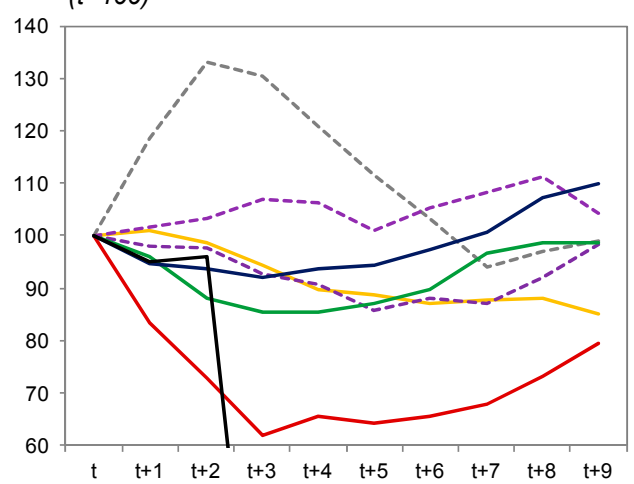

EMBI Global Spreads 4/

(change relative to $t=0$ )

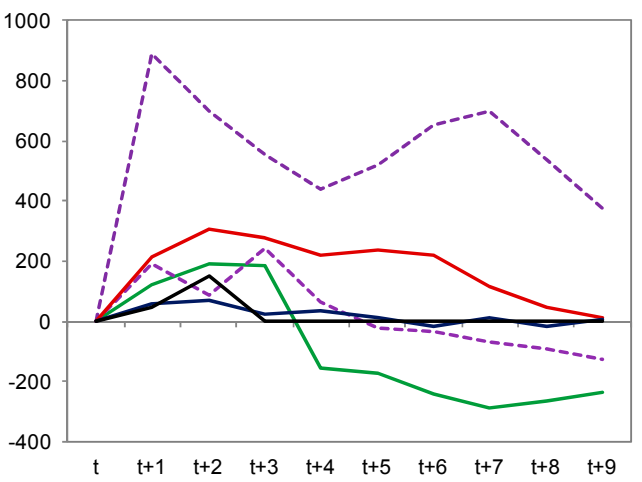

Average Consensus Forecast on GDP growth for following 12 months $6 /$

(mean, $t=0$ )

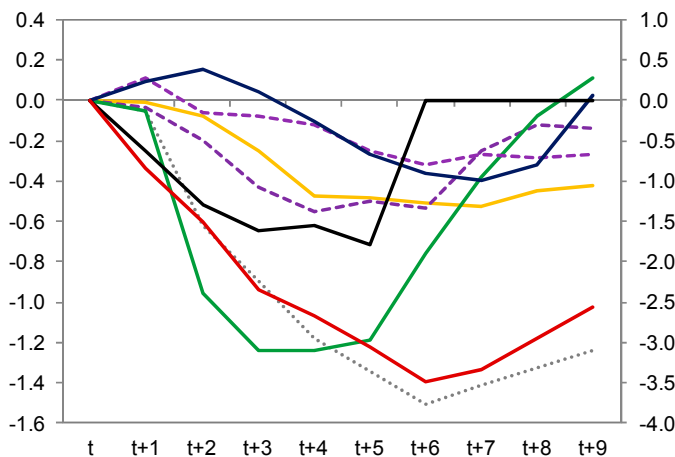

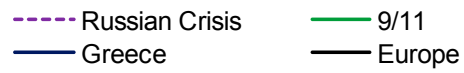

Advanced Markets Industrial Production 3/ (normalized, $t=0$ )

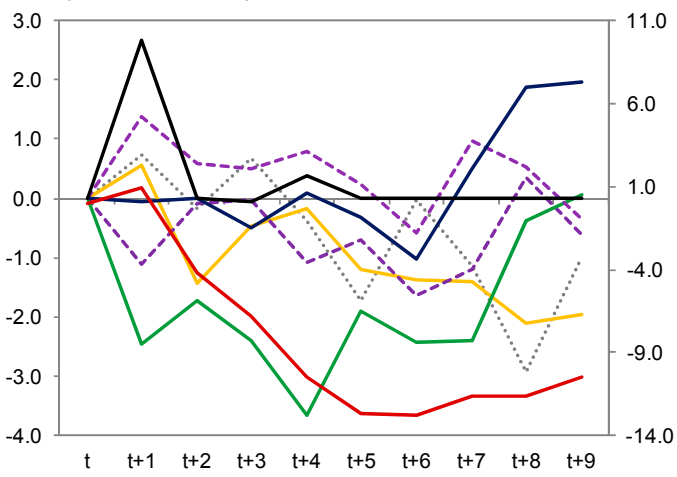

EM Mutual Fund Flows 5/

(cumulative, \% of assets)

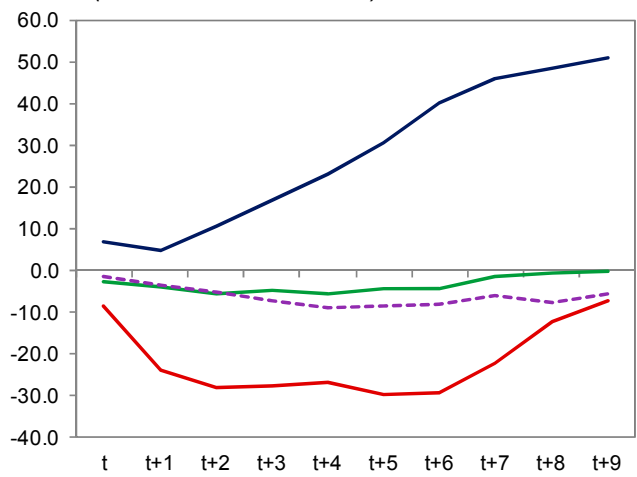

Dispersion of Growth Concensus Forecast for following 12 months $6 /$ (standard deviation, $t=0$ )

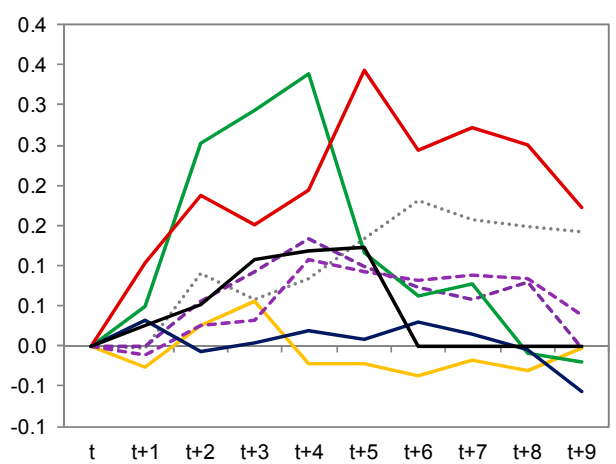

Source: IMF International Financial Statistics, Consensus Forecast, Haver and authors' calculations.

$1 /$ Months reported in horizontal axis. $t=0$ is start of the episode as identified in Figure [1].

2/ Broad IMF commodity price index, in real terms, adjusted for exchange rate valuation effects (see Adler and Sosa, 2011). 3/ Change in cyclical component of industrial production. Weighted average for US, Japan, Germany and France.

4/ Data for Gulf War and Asian crisis episodes are not available.

5/ Flows to EM equity mutual funds, in percent of total assets under management. Excludes episodes prior to 2000 due to lack of data.

6/ Weighted average for US, Japan, Germany, France and UK. Linear combination of concensus forecast for current and following yeart, with weight for current year proportional to months left.

\section{CInternational Monetary Fund. Not for Redistribution}




\section{ANNEX 2}

Exchange Rate Pressures during Global Financial Shocks 1/ (exchange rate market pressure index, medians)
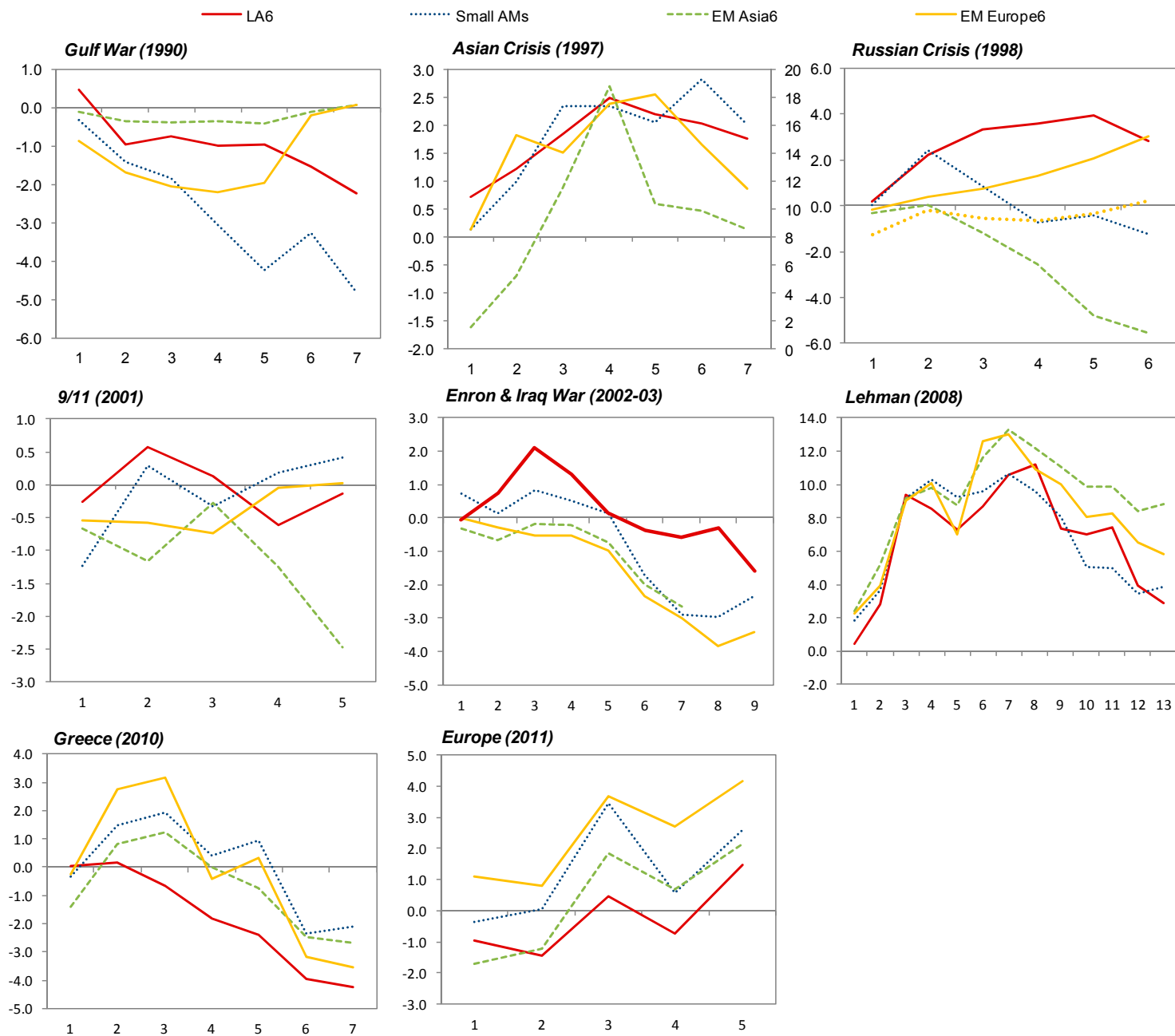

Source: IMF staff calculations

$1 /$ Exchange rate market pressure index, composed of changes in central bank's net foreign assets and exchange rate vis-a-vis US dollar.(each component normalized by its standard deviation). Increase indicates depreciation pressures. Medians for each group are reported. Months from the beginning of episode are reported in horizontal axis. 
Annex Table A1: Sample Coverage and Sources for Real GDP and IP

\begin{tabular}{|c|c|c|c|c|c|c|c|c|}
\hline \multirow{3}{*}{ Group } & \multirow{3}{*}{ Country } & \multirow{3}{*}{ IFS code } & \multicolumn{4}{|c|}{ Original Sources } & \multicolumn{2}{|r|}{ Hybrid Series } \\
\hline & & & \multicolumn{2}{|c|}{$\begin{array}{c}\text { Real GDP (national } \\
\text { accounts) }\end{array}$} & \multicolumn{2}{|c|}{ Other } & \multirow[t]{2}{*}{ Start } & \multirow[t]{2}{*}{ Chain } \\
\hline & & & Haver 1/ & IMF 2/ & IMAE 3/ & IP 4/ & & \\
\hline EM & Argentina & 213 & 1980 & 1993 & & 1990 & 1980 & No \\
\hline EM & Bolivia & 218 & 1990 & & & 1990 & 1990 & No \\
\hline EM & Brazil & 223 & 1980 & 1996 & & & 1980 & No \\
\hline EM & Bulgaria & 918 & 1995 & & & 1995 & 1995 & 2011Q4 \\
\hline EM & Chile & 228 & 1986 & 1996 & & 1990 & 1986 & No \\
\hline EM & China & 924 & 1992 & 1991 & & 1997 & 1991 & No \\
\hline EM & Colombia & 233 & 1980 & 1994 & & 1990 & 1980 & No \\
\hline EM & Costa Rica & 238 & 1991 & & 1991 & 1985 & 1985 & 2011Q4 \\
\hline EM & Croatia & 960 & 2000 & 1997 & & 1991 & 1991 & 1991Q1-1997Q1 \\
\hline EM & Czech Republic & 935 & 1996 & 1996 & & 1993 & 1993 & No \\
\hline EM & Dominican Republic & 243 & 1990 & & & 2002 & 1990 & No \\
\hline EM & Ecuador & 248 & 1990 & & & 1991 & 1990 & 2011Q4 \\
\hline EM & El Salvador & 253 & 1990 & & & & 1990 & 2011Q4 \\
\hline EM & Estonia & 939 & 1995 & 1994 & & 2000 & 1994 & No \\
\hline EM & Guatemala & 258 & 2001 & & 1993 & 2002 & 1993 & 1993Q1-2001Q1 \\
\hline EM & Hungary & 944 & 1995 & 1995 & & 1998 & 1995 & No \\
\hline EM & India & 534 & 1996 & 1996 & & 2000 & 1996 & No \\
\hline EM & Indonesia & 536 & 1983 & 1993 & & 1993 & 1983 & No \\
\hline EM & Iran & 429 & 1988 & & & & 1988 & No \\
\hline EM & Jamaica & 343 & 1996 & & & & 1996 & No \\
\hline EM & Jordan & 439 & 1992 & & & 2000 & 1992 & 2011Q4 \\
\hline EM & Latvia & 941 & 1992 & 1995 & & & 1992 & No \\
\hline EM & Lithuania & 946 & 1995 & 1995 & & & 1995 & No \\
\hline EM & Malaysia & 548 & 1991 & & & 1985 & 1985 & 1985Q1-1991Q1 \\
\hline EM & Mexico & 273 & 1980 & 1993 & & 1985 & 1980 & No \\
\hline EM & Paraguay & 288 & 1994 & & & 2000 & 1994 & 2011Q4 \\
\hline EM & Peru & 293 & 1980 & 1994 & & & 1980 & No \\
\hline EM & Philippines & 566 & 1981 & 1997 & & 1998 & 1981 & No \\
\hline EM & Poland & 964 & 1995 & & & 1990 & 1990 & 2011Q4 \\
\hline EM & Romania & 968 & 2000 & & & 2000 & 2000 & 2011Q4 \\
\hline EM & Russia & 922 & 1995 & 1991 & & 2000 & 1991 & No \\
\hline EM & Serbia & 965 & 2001 & 1997 & & & 1997 & No \\
\hline EM & Slovakia & 936 & 1997 & 1997 & & 2002 & 1997 & No \\
\hline EM & Slovenia & 961 & 1996 & 1996 & & 2005 & 1996 & 1992Q1-1996Q1 \\
\hline EM & South Africa & 199 & 1980 & 1990 & & 1990 & 1980 & No \\
\hline EM & South Korea & 542 & 1980 & 1990 & & 1990 & 1980 & No \\
\hline EM & Thailand & 578 & 1993 & 1993 & & & 1993 & No \\
\hline EM & Turkey & 186 & 1987 & 1987 & & 1985 & 1985 & 1985Q1-1987Q1 \\
\hline EM & Ukraine & 926 & 2001 & & & 1994 & 1994 & 2011Q4 \\
\hline EM & Uruguay & 298 & 1980 & & & 1997 & 1980 & 2011Q4 \\
\hline EM & Venezuela & 299 & 1994 & 1997 & & & 1994 & No \\
\hline Small AM & Australia & 193 & 1980 & 1988 & & 1985 & 1980 & No \\
\hline Small AM & Canada & 156 & 1980 & 1986 & & 1985 & 1980 & No \\
\hline Small AM & Finland & 172 & & 1990 & & & 1990 & No \\
\hline Small AM & Hong Kong, China & 532 & 1980 & 1980 & & 1985 & 1980 & No \\
\hline Small AM & Israel & 436 & 1995 & 1990 & & 1985 & 1985 & No \\
\hline Small AM & New Zealand & 196 & 1987 & 1984 & & & 1984 & No \\
\hline Small AM & Norway & 142 & 1980 & 1998 & & 1985 & 1980 & No \\
\hline Small AM & Singapore & 576 & 1980 & 1983 & & & 1980 & No \\
\hline Small AM & Sweden & 144 & 1980 & 1990 & & & 1980 & No \\
\hline
\end{tabular}

1/ Haver Analy tics.

2/ IMF International Financial Statistics.

3/ Monthly Indicator of Economic Activity.

4/ Industrial Production. 
Annex Table A2. Results of Cross Section Econometric Estimation

\begin{tabular}{|c|c|c|c|c|c|c|c|c|c|c|c|c|c|c|c|c|c|c|}
\hline \multirow{3}{*}{$\begin{array}{c}\text { Dependent Variable } \\
\text { Specification: }\end{array}$} & \multicolumn{18}{|c|}{ Output-Cumulative Deviations from Trend (in percent of trend) $1 /$} \\
\hline & \multicolumn{2}{|c|}{ Basic model } & \multirow{2}{*}{\multicolumn{8}{|c|}{ Amplification of individual fundamentals }} & \multirow[b]{2}{*}{11} & \multirow[b]{2}{*}{12} & \multirow[b]{2}{*}{13} & \multirow[b]{2}{*}{14} & \multirow[b]{2}{*}{15} & \multirow[b]{2}{*}{16} & \multirow[b]{2}{*}{17} & \multirow[b]{2}{*}{18} \\
\hline & $\frac{1}{1}$ & 2 & 3 & & & & & & 9 & 10 & & & & & & & & \\
\hline Variable & & & & & & & & & & & & & & & & & & \\
\hline VIX & $\begin{array}{l}-0.176^{* * *} \\
(0.018)\end{array}$ & $\begin{array}{l}-0.047^{* * *} \\
(0.017)\end{array}$ & $\begin{array}{l}-0.027 \\
(0.021)\end{array}$ & $\begin{array}{l}-0.052^{* * *} \\
(0.018)\end{array}$ & $\begin{array}{l}-0.044^{* * *} \\
(0.016)\end{array}$ & $\begin{array}{l}-0.066^{* * *} \\
(0.018)\end{array}$ & $\begin{array}{l}-0.044^{* *} \\
(0.019)\end{array}$ & $\begin{array}{l}-0.047^{* *} \\
(0.018)\end{array}$ & $\begin{array}{l}-0.067 * * * \\
(0.020)\end{array}$ & $\begin{array}{l}-0.054^{* * *} \\
(0.017)\end{array}$ & $\begin{array}{l}-0.010 \\
(0.029)\end{array}$ & $\begin{array}{l}-0.008 \\
(0.022)\end{array}$ & $\begin{array}{l}0.013 \\
(0.028)\end{array}$ & $\begin{array}{l}-0.044^{*} \\
(0.024)\end{array}$ & $\begin{array}{l}-0.037 \\
(0.026)\end{array}$ & $\begin{array}{l}-0.015 \\
(0.040)\end{array}$ & $\begin{array}{l}-0.009 \\
(0.032)\end{array}$ & $\begin{array}{l}-0.018 \\
(0.022)\end{array}$ \\
\hline Trade Channel & & $\begin{array}{l}0.117^{* * *} \\
(0.019)\end{array}$ & $\begin{array}{l}0.118^{* * *} \\
(0.019)\end{array}$ & $\begin{array}{l}0.114^{* * *} \\
(0.020)\end{array}$ & $\begin{array}{l}0.117^{* * *} \\
(0.018)\end{array}$ & $\begin{array}{l}0.117^{* * *} \\
(0.019)\end{array}$ & $\begin{array}{l}0.111^{* * *} \\
(0.020)\end{array}$ & $\begin{array}{l}0.115^{* * *} \\
(0.019)\end{array}$ & $\begin{array}{l}0.113^{* * *} \\
(0.018)\end{array}$ & $\begin{array}{l}0.115^{* * *} \\
(0.018)\end{array}$ & $\begin{array}{l}0.118^{* * *} \\
(0.020)\end{array}$ & $\begin{array}{l}0.121^{* * *} \\
(0.018)\end{array}$ & $\begin{array}{l}0.114^{* * *} \\
(0.019)\end{array}$ & $\begin{array}{l}0.111^{* * *} \\
(0.020)\end{array}$ & $\begin{array}{l}0.115^{* * *} \\
(0.019)\end{array}$ & $\begin{array}{l}0.117 * * * \\
(0.021)\end{array}$ & $\begin{array}{l}0.115^{* * *} \\
(0.019)\end{array}$ & $\begin{array}{l}0.114^{* * *} \\
(0.018)\end{array}$ \\
\hline \multicolumn{19}{|l|}{ Interaction of VIX with: } \\
\hline Financial Integration & & & $\begin{array}{l}-0.027+ \\
(0.019)\end{array}$ & & & & & & & & $\begin{array}{l}-0.047^{* *} \\
(0.023)\end{array}$ & $\begin{array}{l}-0.042^{* *} \\
(0.019)\end{array}$ & $\begin{array}{l}-0.107^{\star \star \star} \\
(0.038)\end{array}$ & $\begin{array}{l}0.003 \\
(0.027)\end{array}$ & $\begin{array}{l}-0.022 \\
(0.026)\end{array}$ & $\begin{array}{l}-0.034 \\
(0.036)\end{array}$ & $\begin{array}{l}-0.079^{*} \\
(0.041)\end{array}$ & $\begin{array}{l}-0.049^{* *} \\
(0.023)\end{array}$ \\
\hline NFA & & & & $\begin{array}{l}-0.000 \\
(0.000)\end{array}$ & & & & & & & $\begin{array}{l}0.001 \\
(0.001)\end{array}$ & & & & & & & \\
\hline Current Account & & & & & $\begin{array}{l}0.001^{*} \\
(0.001)\end{array}$ & & & & & & & $\begin{array}{l}0.005+ \\
(0.003)\end{array}$ & & & & & & \\
\hline Exchange Rate Flexibility & & & & & & $\begin{array}{l}0.046^{* *} \\
(0.018)\end{array}$ & & & & & & & $\begin{array}{l}-0.108^{* *} \\
(0.046)\end{array}$ & & & & & \\
\hline Dollarization & & & & & & & $\begin{array}{l}-0.000 \\
(0.000)\end{array}$ & & & & & & & $\begin{array}{l}0.001 \\
(0.001)\end{array}$ & & & & \\
\hline International Reserves & & & & & & & & $\begin{array}{l}-0.000 \\
(0.000)\end{array}$ & & & & & & & $\begin{array}{l}0.001 \\
(0.002)\end{array}$ & & & \\
\hline External Debt & & & & & & & & & & & & & & & & $\begin{array}{l}-0.001 \\
(0.001)\end{array}$ & & \\
\hline Public Debt & & & & & & & & & $\begin{array}{l}0.000^{* *} \\
(0.000)\end{array}$ & & & & & & & & $\begin{array}{l}-0.000 \\
(0.001)\end{array}$ & \\
\hline Primary Fiscal Balance & & & & & & & & & & $\begin{array}{l}0.002+ \\
(0.001)\end{array}$ & & & & & & & & $\begin{array}{l}-0.007^{\star} \\
(0.004)\end{array}$ \\
\hline \multicolumn{19}{|c|}{ Interaction of VIX with Financial Intergration and: } \\
\hline NFA & & & & & & & & & & & $\begin{array}{l}-0.001 \\
(0.001)\end{array}$ & & & & & & & \\
\hline Current Account & & & & & & & & & & & & $\begin{array}{l}-0.004 \\
(0.004)\end{array}$ & & & & & & \\
\hline Exchange Rate Flexibility & & & & & & & & & & & & & $0.212^{* * *}$ & & & & & \\
\hline Dollarization & & & & & & & & & & & & & & $\begin{array}{l}-0.002+ \\
(0.001)\end{array}$ & & & & \\
\hline International Reserves & & & & & & & & & & & & & & & $\begin{array}{l}-0.001 \\
(0.002)\end{array}$ & & & \\
\hline External Debt & & & & & & & & & & & & & & & & $\begin{array}{l}0.000 \\
(0.001)\end{array}$ & & \\
\hline Public Debt & & & & & & & & & & & & & & & & & 0.001 & \\
\hline Primary Fiscal Balance & & & & & & & & & & & & & & & & & & $\begin{array}{l}0.011^{* *} \\
(0.004)\end{array}$ \\
\hline Constant & $\begin{array}{l}15.757^{* * *} \\
(1.756)\end{array}$ & $\begin{array}{l}4.011^{* *} \\
(1.619)\end{array}$ & $\begin{array}{l}3.762^{* *} \\
(1.605)\end{array}$ & $\begin{array}{l}4.296^{* *} \\
(1.714)\end{array}$ & $\begin{array}{l}3.758^{* *} \\
(1.582)\end{array}$ & $\begin{array}{l}3.379^{* *} \\
(1.639)\end{array}$ & $\begin{array}{l}4.306^{* *} \\
(1.694)\end{array}$ & $\begin{array}{l}4.202^{\star *} \\
(1.688)\end{array}$ & $\begin{array}{l}4.073^{* *} \\
(1.635)\end{array}$ & $\begin{array}{l}4.143^{* \star} \\
(1.629)\end{array}$ & $\begin{array}{l}3.732^{* *} \\
(1.731)\end{array}$ & $\begin{array}{l}3.192^{* *} \\
(1.548)\end{array}$ & $\begin{array}{l}3.129^{*} \\
(1.635)\end{array}$ & $\begin{array}{l}3.966^{* *} \\
(1.669)\end{array}$ & $\begin{array}{l}4.122^{* *} \\
(1.671)\end{array}$ & $\begin{array}{l}4.270^{* \star} \\
(1.650)\end{array}$ & $\begin{array}{l}3.434^{* *} \\
(1.637)\end{array}$ & $\begin{array}{l}3.587^{* \star} \\
(1.632)\end{array}$ \\
\hline Observations & 337 & 33 & 3 & 3 & 32 & 282 & 29 & 31 & 318 & 310 & 316 & 326 & 282 & 299 & 317 & 312 & 318 & 310 \\
\hline R-squared & 0.418 & 0.562 & 0.566 & 0.560 & 0.570 & 0.605 & 0.552 & 0.561 & 0.573 & 0.591 & 0.569 & 0.581 & 0.630 & 0.561 & 0.568 & 0.566 & 0.585 & 0.610 \\
\hline $\mathrm{F}$ & 98.24 & 68.37 & 49.90 & 52.50 & 49.24 & 42.90 & 40.95 & 50.01 & 52.62 & 51.43 & 35.49 & 33.47 & 32.04 & 27.14 & 35.63 & 31.18 & 36.59 & 37.30 \\
\hline
\end{tabular}

Ro* $p<0.01,{ }^{* *} p<0.05,{ }^{*} p<0.10,+p<0.15$
$*$ 
Annex Table A3. Results of Cross Section Econometric Estimation

\begin{tabular}{|c|c|c|c|c|c|c|c|c|c|}
\hline \multirow[t]{2}{*}{ Dependent Variable: } & \multicolumn{9}{|c|}{ Output- Cumulative Deviations from Trend (in percent of trend) } \\
\hline & \multicolumn{7}{|c|}{ Interaction of relevant fundamentals with financial integration } & \multirow{2}{*}{$\begin{array}{c}\text { Main } \\
26\end{array}$} & \multirow{2}{*}{$\begin{array}{c}\begin{array}{c}\text { Robustne } \\
\text { ss check }\end{array} \\
27\end{array}$} \\
\hline Specification: & 19 & 20 & 21 & 22 & 23 & 24 & 25 & & \\
\hline \multicolumn{10}{|l|}{ Variable } \\
\hline VIX & $\begin{array}{l}0.026 \\
(0.027)\end{array}$ & $\begin{array}{l}-0.018 \\
(0.033)\end{array}$ & $\begin{array}{l}0.062+ \\
(0.043)\end{array}$ & $\begin{array}{l}0.027 \\
(0.037)\end{array}$ & $\begin{array}{l}0.015 \\
(0.030)\end{array}$ & $\begin{array}{l}0.034 \\
(0.033)\end{array}$ & $\begin{array}{l}0.012 \\
(0.034)\end{array}$ & $\begin{array}{l}0.010 \\
(0.028)\end{array}$ & $\begin{array}{l}0.008 \\
(0.034)\end{array}$ \\
\hline Trade Channel & $\begin{array}{l}0.117^{* * *} \\
(0.018)\end{array}$ & $\begin{array}{l}0.114^{* * *} \\
(0.020)\end{array}$ & $\begin{array}{l}0.116^{* * *} \\
(0.020)\end{array}$ & $\begin{array}{l}0.111^{* * *} \\
(0.019)\end{array}$ & $\begin{array}{l}0.113^{* * *} \\
(0.019)\end{array}$ & $\begin{array}{l}0.118^{* * *} \\
(0.021)\end{array}$ & $\begin{array}{l}0.110^{* * *} \\
(0.020)\end{array}$ & $\begin{array}{l}0.113^{* * *} \\
(0.020)\end{array}$ & \\
\hline Terms of Trade & & & & & & & & & $\begin{array}{l}7.637^{* *} \\
(3.553)\end{array}$ \\
\hline World GDP & & & & & & & & & $\begin{array}{l}0.945^{\star * *} \\
(0.207)\end{array}$ \\
\hline \multicolumn{10}{|l|}{ Interaction of VIX with: } \\
\hline Financial Integration & $\begin{array}{l}-0.117^{* * *} \\
(0.035)\end{array}$ & $\begin{array}{l}-0.082^{*} \\
(0.045)\end{array}$ & $\begin{array}{l}-0.148^{* \star *} \\
(0.055)\end{array}$ & $\begin{array}{l}-0.154^{* * *} \\
(0.051)\end{array}$ & $\begin{array}{l}-0.114^{* \star *} \\
(0.042)\end{array}$ & $\begin{array}{l}-0.126^{\star * *} \\
(0.039)\end{array}$ & $\begin{array}{l}-0.108^{*} \\
(0.056)\end{array}$ & $\begin{array}{l}-0.077+ \\
(0.049)\end{array}$ & $\begin{array}{l}-0.123^{* *} \\
(0.049)\end{array}$ \\
\hline NFA & & & & & & $\begin{array}{l}0.001 \\
(0.001)\end{array}$ & & & \\
\hline Current Account & $\begin{array}{l}0.007^{* *} \\
(0.003)\end{array}$ & & & & & & & $\begin{array}{l}0.001+ \\
(0.001)\end{array}$ & $\begin{array}{l}0.001 \\
(0.001)\end{array}$ \\
\hline Exchange Rate Flexibility & $\begin{array}{l}-0.097^{* *} \\
(0.041)\end{array}$ & $\begin{array}{l}-0.097^{* *} \\
(0.046)\end{array}$ & $\begin{array}{l}-0.119^{* *} \\
(0.046)\end{array}$ & $\begin{array}{l}-0.114^{* *} \\
(0.046)\end{array}$ & $\begin{array}{l}-0.090^{*} \\
(0.050)\end{array}$ & $\begin{array}{l}-0.103^{* *} \\
(0.045)\end{array}$ & $\begin{array}{l}-0.112^{* *} \\
(0.052)\end{array}$ & $\begin{array}{l}-0.096^{*} \\
(0.046)\end{array}$ & $\begin{array}{l}-0.117^{*} \\
(0.050)\end{array}$ \\
\hline Dollarization & & & & & & & $\begin{array}{l}-0.000 \\
(0.001)\end{array}$ & & \\
\hline International Reserves & & $\begin{array}{l}0.002 \\
(0.002)\end{array}$ & & & & & & & \\
\hline External Debt & & & $\begin{array}{l}-0.002^{*} \\
(0.001)\end{array}$ & & & & & $\begin{array}{l}-0.000 \\
(0.000)\end{array}$ & $\begin{array}{l}-0.000 \\
(0.000)\end{array}$ \\
\hline Public Debt & & & & $\begin{array}{l}-0.000 \\
(0.001)\end{array}$ & & & & & \\
\hline Primary Fiscal Balance & & & & & $\begin{array}{l}-0.005 \\
(0.004)\end{array}$ & & & & \\
\hline \multicolumn{10}{|c|}{ Interaction of VIX with Financial Intergration and: } \\
\hline NFA & & & & & & $\begin{array}{l}-0.001 \\
(0.001)\end{array}$ & & & \\
\hline Current Account & $\begin{array}{l}-0.007^{*} \\
(0.004)\end{array}$ & & & & & & & & \\
\hline Exchange Rate Flexibility & $\begin{array}{l}0.201^{* * *} \\
(0.060)\end{array}$ & $\begin{array}{l}0.198^{* * *} \\
(0.068)\end{array}$ & $\begin{array}{l}0.227^{* * *} \\
(0.072)\end{array}$ & $\begin{array}{l}0.221^{* * *} \\
(0.065)\end{array}$ & $\begin{array}{l}0.181^{\text {** }} \\
(0.071)\end{array}$ & $\begin{array}{l}0.204^{* * *} \\
(0.067)\end{array}$ & $\begin{array}{l}0.219^{* * *} \\
(0.084)\end{array}$ & $\begin{array}{l}0.190^{* * *} \\
(0.070)\end{array}$ & $\begin{array}{l}0.235^{* * *} \\
(0.074)\end{array}$ \\
\hline Dollarization & & & & & & & $\begin{array}{l}0.000 \\
(0.001)\end{array}$ & & \\
\hline International Reserves & & $\begin{array}{l}-0.002 \\
(0.002)\end{array}$ & & & & & & & \\
\hline External Debt & & & $\begin{array}{l}0.002^{*} \\
(0.001)\end{array}$ & & & & & & \\
\hline Public Debt & & & & $\begin{array}{l}0.001 \\
(0.001)\end{array}$ & & & & & \\
\hline Primary Fiscal Balance & & & & & $\begin{array}{l}0.008+ \\
(0.005)\end{array}$ & & & & \\
\hline Constant & $\begin{array}{l}2.879^{*} \\
(1.517)\end{array}$ & $\begin{array}{l}3.573^{* *} \\
(1.716)\end{array}$ & $\begin{array}{l}3.704^{* *} \\
(1.676)\end{array}$ & $\begin{array}{l}2.748^{*} \\
(1.659)\end{array}$ & $\begin{array}{l}3.055^{*} \\
(1.661)\end{array}$ & $\begin{array}{l}2.950^{*} \\
(1.772)\end{array}$ & $\begin{array}{l}3.577^{* *} \\
(1.747)\end{array}$ & $\begin{array}{l}3.229^{*} \\
(1.674)\end{array}$ & $\begin{array}{l}4.976^{* * *} \\
(1.819)\end{array}$ \\
\hline Observations & 282 & 275 & 268 & 276 & 270 & 274 & 259 & 268 & 268 \\
\hline R-squared & 0.645 & 0.632 & 0.639 & 0.652 & 0.643 & 0.632 & 0.622 & 0.641 & 0.571 \\
\hline $\mathbf{F}$ & 28.28 & 24.04 & 24.10 & 27.57 & 27.77 & 30.52 & 21.34 & 23.94 & 18.98 \\
\hline
\end{tabular}

